\title{
DESMONTANDO EL INDULTO (ESPECIAL REFERENCIA A LOS DELITOS DE CORRUPCIÓN) ${ }^{1}$

\author{
Dismounting the Pardon (with Special Reference \\ to Corruption Offences)
}

\author{
DULCE M. SANTANA VEGA \\ Universidad de Las Palmas de Gran Canaria \\ dulce.santana@ulpgc.es \\ Cómo citar/Citation \\ Santana Vega, D. M. (2016) \\ Desmontando el indulto (especial referencia a los delitos de corrupción). \\ Revista Española de Derecho Constitucional, 108, 51-91. \\ doi: http://dx.doi.org/10.18042/cepc/redc.108.02
}

Resumen

Este artículo aborda, desde un punto de vista crítico y abolicionista, el análisis del indulto y resalta, a través de diez argumentos principales, lo pernicioso de tal institución para el funcionamiento de los sistemas penales, especialmente cuando se trata de delitos de corrupción. Asimismo, se esbozan otros instrumentos jurídicos alternativos que harían innecesario el indulto en los Estados democráticos de derecho.

\section{Palabras clave}

Indulto; principios del Estado democrático de derecho; proporcionalidad de las penas; dilaciones indebidas; corrupción.

1 Este artículo se enmarca dentro del Proyecto de Investigación: Transparencia institucional, Participación Ciudadana y Lucha contra la Corrupción: Análisis, Evaluación y Propuestas (DER2014-57128-P). 


\section{Abstract}

This article discusses, from a critical and abolitionist view, the pardon, highlighting, through ten main arguments, the negative effects of this institution for the penal systems, especially when it operates in crimes of corruption. Likewise, it outlines other alternative instruments that would make unnecessary the pardon in democratic states of law.

\section{Keywords}

Pardon; principles of democratic State of law; proportionality of sentences; undue delay; corruption. 


\section{SUMARIO}

I. CONSIDERACIONES GENERALES PREVIAS. II. DIEZ ARGUMENTOS EN CONTRA DE LA PERVIVENCIA DEL INDULTO: 1. División de poderes. 2. Principio de legalidad penal. 3. Prohibición de arbitrariedad. 4. Principio de igualdad. 5. Estado aconfesional y justicia penal. 6. Proporcionalidad de las penas. 7. Fines de la pena. 8. Dilaciones indebidas en el enjuiciamiento o en la ejecución de las penas. 9. Suspensión o sustitución de penas por el indulto. 10. Desapoderamiento judicial y desmoralización de los operadores jurídicos. III. CONCLUSIONES. BIBLIOGRAFÍA.

\section{CONSIDERACIONES GENERALES PREVIAS}

El derecho de gracia ya era conocido por los pueblos primitivos; siendo una práctica constante durante toda la Edad $\mathrm{Media}^{2}$. Con posterioridad, en la época de las monarquías absolutas, el poder de otorgar la gracia se erige como una manifestación más del derecho a impartir justicia por parte del monarca absoluto, titular de la soberanía, en el marco de un sistema judicial arbitrario y en el contexto de una generalizada corrupción institucional.

El derecho de gracia se ha ejercido tradicionalmente a través de dos instituciones: la amnistía - de cuya vigencia ante el silencio de la Constitución española (CE) y del Código Penal se duda ${ }^{3}$ - y los indultos, clasificados en generales y particulares.

Por lo que a los indultos generales se refiere, su uso fue frecuente bajo el régimen franquista, quien los prefirió a las amnistías ${ }^{4}$. Estos indultos están en la actualidad expresamente prohibidos en la CE (art. 62, i).

2 Vid. sobre la evolución del derecho de gracia, entre otros: García Mahamut (2004: 22 y ss.); Herrero Bernabé (2012: 687 y 688).

3 A favor, entre otros, Aguado Renedo (2001: 74 y ss.) García Arán (2009: 187 y ss.); Mir Puig (2015: 757); Sánchez-Vera Gómez-Trelles (2008: 7). En contra, por todos, Cobo Del Rosal; Vives Antón (1999: 716); Orts Berenguer; González Cussac (2004: 206).

4 El Decreto de 22 de abril de 1938 rehabilita la Ley del Indulto de 1870 y admite los indultos generales, prohibidos en la II República. En la Exposición de Motivos del citado Decreto se afirma que: «El Nuevo Estado busca en la constante histórica de 
Por último, habría que hacer referencia al indulto particular, el cual es la única modalidad del derecho de gracia que se recoge expresamente en el Código Penal como causa de extinción de la responsabilidad criminal (art. 130.4. ${ }^{\circ}$ ), estando regulado por la Ley de 18 de junio de 1870, de Reglas para el Ejercicio de la Gracia de Indulto, modificada por la Ley 1/1988, de 14 de enero5.

El indulto puede extinguir la pena de forma total o parcial (arts. 1 y 4 de la Ley de Indulto [LI]), pero no sus efectos: antecedentes penales, responsabilidad civil (art. 6-II LI), consecuencias accesorias, y tampoco se extenderá a las costas procesales (art. $9 \mathrm{LI}$ ). En cuanto a las penas accesorias habrá que estar a lo que se disponga en los Reales Decretos que los conceden (arts. 6-I, 7 y 13 LI). La aplicación del indulto no está prevista para casos ajenos al orden penal (derecho administrativo sancionador o disciplinario) ${ }^{6}$.

\section{DIEZ ARGUMENTOS EN CONTRA DE LA PERVIVENCIA DEL INDULTO}

En las líneas que se esbozan a continuación se intentará poner de manifiesto lo anacrónico y contraproducente de la pervivencia de la institución del

nuestro Derecho patrio, la directriz del futuro ordenamiento, por lo que encierra ansias totalitarias, proclama la unidad del Poder, sin tibiezas ni divisiones bizantinas». $\mathrm{Al}$ amparo de la citada normativa se concedieron, entre otros, los de: 9 de octubre de 1945, con motivo del IX aniversario de la exaltación de Franco a la Jefatura del Estado; 17 de Julio de 1947 para conmemorar la ratificación de la Ley de Sucesión a la Jefatura del Estado; 8 de diciembre de 1949, con motivo del Año Santo; 1 de mayo de 1957, para conmemorar el Congreso Eucarístico de Barcelona; 34 de julio de 1954, con ocasión del Año Jacobeo; 31 de octubre de 1958, con motivo de la coronación de su santidad el Papa Juan XXIII; 25 de Julio de 1965, con ocasión del Año Jubilar compostelano. Vid. sobre este particular, Requejo Pagés (2001: 100).

5 Esta Reforma estuvo antecedida por el Anteproyecto de Ley Reguladora de la Gracia de Indulto, de 23 de junio de 1981, la cual preveía que el indulto abarcara a toda clase de sanciones, sin limitarse expresamente a las de naturaleza penal, con una total judicialización de los indultos, ya que les atribuía su concesión a los organismos jurisdiccionales en nombre del Rey. En el expediente debía figurar la intervención del Tribunal competente, del Ministerio Fiscal, la del juez de Vigilancia, en su caso, así como la de una Comisión Consultiva ad hoc que se creaba para la valoración imparcial de las circunstancias concurrentes.

6 Vid. con citas jurisprudenciales, Magro Servet (2007: 1 y ss.); no pudiendo considerarse como indulto, a estos efectos, la revocación de actos administrativos prevista en el art. 105 de la LRJPAC. 
indulto en los Estados democráticos de derecho no solo desde el punto de vista de los principios que lo rigen, sino también por las significativas perturbaciones que introduce en el sistema penal, las cuales se agudizan cuando se trata de acometer la lucha contra los delitos de corrupción, tanto pública como privada.

\section{DIVISIÓN DE PODERES}

La división o separación de poderes es un principio básico del Estado de derecho, sobre todo en los Estados continentales europeos ${ }^{8}$. Este principio es entendido como aquel por el que se distribuyen funciones entre los órganos del Estado, en atención a sus propias características estructurales y al poder en el que se incardinan'.

La división de poderes es un fenómeno más empírico que dogmático. Desde su surgimiento en la época de la Ilustración francesa ha estado siempre inconcluso y ha necesitado de una constante actualización y de ser vivificado en su esencia y en sus reajustes ${ }^{10}$.

De entre las patologías que pueden afectar a la división de poderes destaca, por su gravedad, aquellas que implicarían el uso del poder coercitivo del Estado para, de una manera u otra, promover intereses particulares de grupos de presión (económicos, políticos o sociales) ${ }^{11}$. La gravedad de esta patología

7 Rubio Llorente (2004: 224) aclara que la división de poderes es la denominación propia de los regímenes parlamentarios, mientras que el término separación es más propio de los presidencialistas, distinguiendo también entre la «división horizontal y la vertical —-territorial- de poderes».

8 A diferencia del modelo anglosajón en el que no existe propiamente un poder judicial independiente, ya que los jueces en el sistema del common law, además de aplicar las normas, las crean a través de los precedentes, sin olvidar que la Cámara de los Lores constituye el Tribunal Supremo del Reino Unido, al mismo tiempo que coautor, junto a la Cámara de los Comunes, de las leyes de tal Estado. Vid. entre otros, Mortati (1973:145 y ss.).

9 Ampliamente sobre su evolución histórica y la crítica doctrinal al principio, Solozabal Echevarría (1981: 215 y ss.).

10 Vid. Lucas Verdú (1974: 133 y ss.); en la misma línea, García Roca (2000: 70).

11 Así, la STS, Sala Tercera, Sección 6. a, 546/2013, de 20 febrero, declaró la extralimitación del Gobierno en el indulto a dos banqueros (BOE núm. 297, de 10-12.2011), al dispensarles del requerimiento de carecer de antecedentes penales para el ejercicio de la actividad bancaria. Una vez conocida la citada Sentencia, el Consejo de Ministros aprobó, en poco más de un mes, el Real Decreto 256/2013, de 12 de abril, por el que se incorporan a la normativa de las entidades de crédito los criterios de la Autoridad 
se incrementa cuando el afectado es el poder judicial, dado su carácter de garante de derechos individuales y colectivos ${ }^{12}$.

El indulto es una institución extraña que subsiste en el régimen constitucional, basado en la separación de poderes, pese a ser un claro exponente de la unión o concentración de estos ${ }^{13}$, lo que conculca la independencia judicial ${ }^{14}$. Es un contrasentido que en el texto constitucional se siga otorgando al monarca parlamentario, por mera inercia ${ }^{15}$, el derecho de gracia. Tampoco puede considerarse justificada la pervivencia del indulto por el mero hecho de que la CE establezca su sumisión a la ley, ya que tal sumisión, como se verá más adelante, es meramente formal ${ }^{16}$.

El indulto supone una vía para enmendar, en un caso particular, la aplicación de la ley penal mediante una sentencia firme, pero sin que se inste recurso alguno en el seno del poder judicial, o sin que se lleve a cabo un proceso

Bancaria Europea de 22 de noviembre de 2012, sobre la evaluación de la adecuación de los miembros del órgano de administración y de los titulares de funciones clave, suprimiendo la referencia a los antecedentes penales y que estos supusieran un inconveniente para mantenerse en sus cargos. En la nueva redacción, además de no contener mención alguna expresa de los citados antecedentes penales, se establece como criterio de ponderación para determinar la denominada «honorabilidad bancaria», en caso de sanciones administrativas o penales, el de «la posible extinción de la responsabilidad penal», lo que supone una clara referencia al indulto.

12 Sobre una sistematización de las patologías de la división de poderes, vid. Málem Seña; Selee (2013: p. 275 y ss.). De límite poco justificado de la separación de poderes califican al indulto, entre otros, Bueno Ochoa (2007: 41 y ss., 55 y ss.).

13 Vid. López Aguilar (2004: 11 y 12).

14 Según se establece en la Declaración de Derechos del Hombre y del Ciudadano de 1789: "Toda sociedad en la cual la garantía de los derechos no está asegurada, ni la separación de poderes determinada, no tiene Constitución. Por ello, las excepciones a la separación de poderes solo pueden ser extraordinarias, previstas en la Constitución y controlables», aspecto este último que como se verá no se cumple en el indulto. Vid. también, Sequeros Sazatornil (2005: 963 y 968).

15 Lafuente Balle (1997: 257 y ss.), considera por el contrario que el derecho de gracia es una de las facultades configuradoras de la posición jurídico-constitucional del rey y de su relación con los otros poderes del Estado, si bien estima que debió condicionarse a un dictamen favorable del Tribunal Supremo. Por su parte, López Aguilar (1996: 332) entiende que debido a la irresponsabilidad del rey y en virtud de la institución del refrendo (art. $64 \mathrm{CE}$ ), pese al silencio que guarda la Constitución a este respecto, la competencia corresponde al gobierno o, en su caso, a los ministros competentes.

16 Fanlo Loras (1991): 1967 y n. 10. 
legislativo de reforma que permita la aplicación de una nueva ley penal más favorable o, simplemente, su derogación ${ }^{17}$.

Con tales antecedentes no es de extrañar que se afirme que el indulto adolece de motivaciones netamente políticas o meramente coyunturales ${ }^{18}$, las cuales se manifiestan de diversas formas.

a) Cuando se indultan penas impuestas por delitos cometidos por políticos o funcionarios públicos en el ejercicio de sus funciones a correligionarios del Gobierno que los concede ${ }^{19}$.

b) En casos de condenados sin relevancia pública, pero sí la de sus abogados defensores, los cuales, debido a sus conexiones con el poder, encuentran en el indulto una cuarta instancia que no está al alcance de todos los condenados, sobre todo con relación a ciertos delitos en lo que no se suele admitir el indulto ${ }^{20}$.

17 Propone otras medidas anticorrupción, Gimeno Sendra (2013: 2 y ss.), tanto preventivas como represivas, procesales y sustantivas. Específicamente con relación al indulto, Nieva Fenoll (2013: 18) lo califica como «intromisión ilegítima del poder ejecutivo en el poder judicial». Por su parte, el Tribunal Constitucional alemán (BVerfG, 1 BvR 127/10 vom 16.2.2012, Absatz-Nr. 1-33) ha puesto de manifiesto que: «El desarrollo judicial de la ley no debe hacer que el juez establezca su propia idea material de la justicia en lugar de la del Legislador», a lo que habría que añadir, que menos aun cabe que se acometa tal sustitución por parte del ejecutivo mediante el indulto.

18 Ya Pacheco y Gutiérrez Calderón (1843: 269), criticando a los que esgrimían la atribución del indulto al poder judicial, señalaba: «Dios nos libre de los Tribunales, que, prescindiendo de la legalidad, quisieran descender a la política». Más de un siglo después, Linde Paniagua (1976: 403) reconoce que «en la práctica se ha utilizado muchas veces por simples razones coyunturales de política general e incluso como un arma política para evitar condenas a los amigos o cuando políticamente se consideraba conveniente»; en análogo sentido, Pérez Francesch (2009: 57 y ss.).

19 Por todos, Queralt Jiménez (2014: 4) concluye que «el indulto no es más que un lodazal partidista y sectario, administrado por el poder a su antojo»; también, sin proponer su eliminación: Ortego Pérez (2013: 13 y ss.) o Lozano Cutanda (1991: 1044) llaman la atención de los numerosos problemas de su encaje constitucional, debido a su naturaleza singular; Salvini (1981: 1007) considera que el solo reconocimiento del indulto supone un "síntoma de profunda contradicción en el sistema penal». Vid. también nota 57.

20 Indulto de kamikaze valenciano, cuyo abogado defensor pertenecía a un despacho de abogados integrado por un hijo del ministro de Justicia, y cuyo abogado defensor del condenado indultado era hermano de un diputado del Grupo Popular. Este indulto, concedido por RD 16681/2012, de 7 de noviembre, fue anulado por la STS 13/2013, a la que se hará referencia más adelante. 
c) En supuestos en los que el indulto se puede rentabilizar políticamente, mediante la negociación de apoyos para votaciones puntuales o para la consecución de mayorías de gobierno, donde el indulto del correligionario resulta una moneda de cambio en tales negociaciones, lo cual ha venido presuntamente sucediendo en España con los grupos nacionalistas ${ }^{21}$.

d) Cuando su concesión obedece al ejercicio del poder político en su sentido más estricto: esto es, la controvertida razón de Estado, la cual no podría ser sometida a fiscalización por parte del poder judicial so pena de verse afectada la seguridad personal de los que han intervenido en un caso por razones de seguridad o interés nacional ${ }^{22}$. Quizá en este caso es donde el indulto graciable, tal como es concebido en la Ley española, tendría más sentido, pero la proximidad de estos casos a supuestos de terrorismo de Estado y al consiguiente despilfarro de dinero público, mediante el uso de fondos reservados, lo hacen también altamente desaconsejable.

La previsión contenida en el art. 102.3, excluyendo del indulto al presidente y demás miembros del Gobierno, obedece sobre todo a que es el Consejo de Ministros el órgano que concede los indultos. No obstante, este tema ha sido y es muy polémico, y en la Doctrina se ha discutido ${ }^{23}$ la extensión del término miembros del Gobierno; si aquellos quedan excluidos del indulto solo

21 V gr. dirigente de CDC, condenado en 1991 por malversación de caudales públicos, es indultado en 1997 (BOE 9-7-1997) y nombrado después del indulto director general de Relaciones Laborales y Calidad en el Trabajo; dirigente de CiU, condenado en 2003 por haber prevaricado, al conceder la construcción de un pabellón a un amigo suyo (indultado en el BOE núm. 233, de 29-9-2006). Más recientemente, secretario general de la Consejería de Trabajo de CiU, condenado en 2009 como autor de un delito continuado de prevaricación en concurso medial con un delito continuado de malversación de caudales públicos, se le conmuta la pena privativa de libertad impuesta por otra de un año de multa (BOE núm. 62, de 13-3-2012).

22 Vid. sobre la razón de estado en el indulto, Molina Fernández (2011: marg. 6595). Por el contrario, Del Águila Tejerina (2000: 11 y ss.), tras destacar como la Ilustración intentó suprimir las razones del Estado mediante la sumisión de la política al derecho, se opone a la hegemonía del poder judicial sobre los otros poderes y reivindica un espacio teórico y práctico guiado por el juicio, la reflexividad y la prudencia. Sin olvidar que el indulto se puede utilizar también para revocar condenas por delitos contra la vida cometidos por terroristas: indulto concedido por el Consejo de Ministros a una condenada anarquista por un delito de asesinato en grado de tentativa, en concurso ideal con un delito de atentado contra la autoridad y de un delito de tenencia de explosivos (BOE núm. 64, de 15-3-2014).

23 Vid., entre otros, sobre tales cuestiones polémicas que, por la limitada extensión de este trabajo, solo se dejan planteadas: Díez-Picazo (1996: 179 y ss.), García Mahamut 
mientras lo son o si podrían ser indultados con posterioridad por los hechos cometidos durante el ejercicio de sus cargos; y si, en caso afirmativo, quedarían excluidos del indulto solamente por los delitos de traición o contra la seguridad del Estado, únicos a los que alude el art. 102.2 — concepción estricta-, o si tal exclusión de indulto se extendería también al resto de los delitos cometidos en el ejercicio de sus cargos como, por ejemplo, los de corrupción ${ }^{24}$ —concepción amplia-.

e) En otras ocasiones los indultos pueden operar como campañas de imagen que sirven de motivo de contraste con la política criminal del partido político rival o, incluso, en relación a lo previamente mantenido por el mismo partido político ${ }^{25}$.

En definitiva, si una excesiva judicialización de la política conduce, irremediablemente, a la politización de la justicia ${ }^{26}$, la intervención del ejecutivo, mediante los indultos en la ejecución de lo juzgado, supone una politización de la Administración de Justicia en su faceta esencial de hacer ejecutar lo juzgado.

Algún sector de la doctrina constitucionalista propone como solución la sumisión al control parlamentario del poder otorgado por el indulto al Gobierno (art. 66.2 CE), lo que encontraría justificación en la posición constitucional de aquel y en el modelo de Estado recogido en la $\mathrm{CE}^{27}$. Es más, no faltan autores que propugnan, para evitar todos los inconvenientes del modelo actual de indulto, que su concesión se otorgue al Parlamento ${ }^{28}$. Sin embargo, estas propuestas no están exentas de objeciones. En primer lugar, si el indulto fuera otorgado por el Parlamento se convertiría en otra cosa igualmente extraña, esto es: una reforma legislativa para casos particulares.

En segundo lugar, el indulto no puede ser considerado como una acción de Gobierno que debe ser controlada por el Parlamento; ni siquiera como una

(2000: 305 y ss.), Obregón García (1996: 167) y Rodríguez Mourullo (1996: 369 y ss.).

24 Se siguió la postura restrictiva de excluir del indulto únicamente a los delitos consignados en el art. 102.2 de la CE en el RD 2838/1998, de 23 de diciembre, por el que se indulta al exministro del Interior (BOE 22-1-1999); y en el RD 2846/1998, de 23 de diciembre, por el que se indulta al exsecretario de Estado de Seguridad (Caso GALFondos reservados).

25 Vid. BOE núm. 10, de 11-1-2001, p. 1286, en los que se indulta a insumisos condenados por el ya derogado delito de negativa a la prestación del servicio militar; Vid. Zugaldía Espinar (2010): 564.

26 Aragón Reyes (1998: 45).

27 Vid. por todos García Mahamut (2005: 618).

28 Abel Souto (2013: 2 y ss.). 
acción de dirección de la política criminal que, como una modalidad de la política interior corresponde al poder ejecutivo (art. $97 \mathrm{CE})^{29}$, la cual se articula, precisamente, a través de los proyectos de ley orgánica en materia penal que, tras ser aprobados, el indulto derogará en un caso particular.

Por otra parte, el control parlamentario de los indultos no es ni efectivo ni suficiente, sobre todo en los casos de consecución de mayorías absolutas monocolores, porque al existir una correlación entre la mayoría de Gobierno y la parlamentaria, el control que pueda llevarse a cabo desde el Parlamento se convierte en un instrumento meramente formal o estético ${ }^{30}$, o cuando no en una mera estrategia política. Es el denominado «efecto relativizador del principio de división de poderes por la acción de los partidos políticos»" ${ }^{31}$. Pero es que, además, por lo general, el control parlamentario del indulto, dada la falta de publicidad del procedimiento, se va a realizar ex post facto, esto es, cuando ya ha sido concedido de forma irrevocable (art. $18 \mathrm{LI}$ ) y publicado en el $\mathrm{BOE}^{32}$.

Tampoco es una solución acudir al denominado control social de los indultos, ya que en este caso solo serían controlables los indultos mediáticos, como de hecho está pasando, y daría lugar, en el ámbito de la ejecución penal, a una manifestación más de un coyuntural populismo punitivo.

En esta línea argumental se incardina también la exclusión de la prerrogativa de gracia de la iniciativa legislativa popular, la cual persigue evitar el peligro de que tales iniciativas puedan estar dirigidas por una motivación y utilización de carácter políticos; por la instrumentación demagógica por parte

29 Vid. López Aguilar (1996: 329 y ss.) y Navarro Villanueva (2009: 251).

30 Vid. Perez Francesch; Domínguez García (2002: 45): «El «caso Liaño»—en el que concurrió un trasfondo empresarial, mediático y político- ha demostrado cómo una regulación legal que deja las manos — casi- libres al Gobierno para ejercer el derecho de gracia puede hacer tambalear cimientos del Estado de Derecho como son la independencia del Poder Judicial y la separación de poderes». En similar sentido, GarcíaPelayo (1983): 12, pone de manifiesto que «Según el modelo dualista, el Parlamento y el Gobierno no son fácilmente distinguibles ni en cuanto al ámbito real y efectivo de sus atribuciones — que dejan de tener la nítida diferenciación que poseían en el modelo de Montesquieu - ni en cuanto a las fuerzas políticas que representan, ya que ambos están bajo el control de los partidos políticos [...] dado que los miembros del Gobierno y de la mayoría parlamentaria pertenecen necesariamente al mismo partido o coalición de partidos [...]».

31 Sobre el particular: Lucas Garín (2009: 246), Punset Blanco (2009: 15) o Wittreck (2009: 382 y ss.), el cual se refiere a la «indeseable impregnación de todos los órganos del Estado por los partidos políticos».

32 En este sentido, vid. Morales Prats (2011: 812). 
de ciertos grupos, los cuales presionarían para conseguir la gracia para determinados condenados; sin olvidar la complejidad técnica de muchos asuntos y el monopolio estatal del ius puniendi ${ }^{3}$.

En efecto, los medios de comunicación tienen la capacidad de focalizar a la opinión pública hacia un determinado tema — por ejemplo, un determinado indulto-, convirtiéndolo en el centro del debate público, y, por tanto, en un asunto de interés nacional sobre todo en períodos de vacíos informativos. Con ello se llega a generar una extraordinaria presión sobre el poder político para que este actúe de una determinada manera. Por el contrario, un tema - por ejemplo, otro indulto- puede pasar inadvertido. Este fenómeno se conoce como «fijación de temas en la agenda» (agenda setting).

Por otra parte, los medios de comunicación pueden también, a través del denominado "encuadre de la noticia» (framing), dar una determinada interpretación y más importancia al contexto o marco de referencia en el que el hecho queda encuadrado que al hecho mismo. El encuadre de la noticia puede ser: «episódico» — hechos e individuos- o temático —un determinado contexto social, económico o político- . De esta manera, los medios de comunicación pueden crear una concreta imagen de ciertos condenados o del funcionamiento de la justicia penal que será el caldo de cultivo de una política-criminal poco documentada, debido a la influencia de los estereotipos y a la falta de una puesta a disposición de los ciudadanos de la adecuada documentación e información. En definitiva, por esta vía, se hace prevalecer a la opinión publicada sobre la opinión pública informada ${ }^{34}$. Un aspecto que también influye en la concesión de los indultos.

El principio de separación de poderes tolera la interdependencia en la actuación de los poderes, pero con un límite: que ningún poder pueda invadir el ámbito nuclear del otro. Es decir, ningún poder puede alterar el ámbito funcional propio de otro, de tal manera que, por la injerencia, se vea privado el poder injerido de su operatividad básica. En este sentido habría que recordar que la STC 73/2000, de 14 de marzo, FJ 11, ha declarado que una ley que

33 Vid. por todos: Biglino Campos (1987: 108-109), De Esteban y López Guerra (1983: 90).

34 Vid. Varona Gómez (2011: 3, 4, 21, 24, 27 y ss.) y García Arán/Peres-Neto (2008: 25, 27 y 28). Vid. también, Peña Neira (2012: 213), quien apunta que la ausencia de independencia interna y externa de los medios de prensa, debido a la posible concentración de propiedad de estos, puede conllevar pérdida de libertad en los periodistas; en análogo sentido, Cal Martínez (2002: 12 y ss.) señala que «Las presiones y manejos sobre todos los medios de comunicación social que paulatinamente se han ido creando, comienza en la noche de la historia». 
injustificadamente privase de efectos a una decisión judicial firme resultaría contraria al art. 24.1 de la CE, en relación con sus arts. 117.3 y 118.

$\mathrm{Si}$ al poder judicial le corresponde la resolución definitiva de las cuestiones que se les sometan a su jurisdicción, juzgando y haciendo ejecutar lo juzgado, el indulto concedido por el ejecutivo alterará de manera esencial este esquema doblemente: no solo revocará resoluciones judiciales firmes, sino que también impedirá o frustrará el desarrollo especificador de la ley penal promulgada y distorsionará sus efectos en casos particulares ${ }^{35}$.

Por otra parte, la separación de poderes se encuentra estrechamente vinculada a los objetivos de eficacia, en cuanto garantiza una organización racionalizada y la seguridad jurídica mediante la limitación del poder ${ }^{36}$, lo que resulta de especial importancia en el derecho penal. Sin embargo, el indulto, fundado, en último extremo, en razones de conveniencia política, sobre todo en supuestos de corrupción, constituye una excepción injustificada a tan fundamental principio ${ }^{37}$.

\section{PRINCIPIO DE LEGALIDAD PENAL}

Este principio afecta no solo al derecho material o sustantivo, sino al derecho penal global, esto es, ha de regir a lo largo de todo el iter del ejercicio del ius puniendi del Estado, el cual comienza con la actuación de las Fuerzas y Cuerpos de Seguridad del Estado y concluye con la ejecución de las penas impuestas.

El principio de legalidad penal se traduce, al ser este en sí mismo un derecho fundamental, aunque no ejercitable, en la exigencia de Ley Orgánica ${ }^{38}$,

35 De otra opinión, Linde Paniagua (1998: 1823), para quien el indulto particular es una técnica de colaboración entre los poderes ejecutivo y judicial, con preponderancia del primero, y califica la Ley de Indulto de 1870 como «una regulación muy estimable y equilibrada cuya modificación resulta especialmente comprometida», así mismo, considera la amnistía y el indulto como «instrumentos para realizar la Justicia» e interpreta el art. 117.1 de la CE en el sentido de que los jueces no pueden monopolizar la administración de la Justicia..», citando supuestos, cuyos fundamentos son totalmente diversos al del indulto. En análogo sentido, De la Mata Barranco (2007: 279) considera que el indulto es una verdadera supervisión del poder ejecutivo del ejercicio de la justicia por parte del poder judicial. Solozabal Echavarría (1981: 215).

37 Sánchez-Vera Gómez-Trelles (2008: 9).

38 Vid. Queralt Jiménez (1992: 80 y ss). En contra, considerando que el indulto no debe ser regulado por ley orgánica, Aguado Renedo (2001: 68 y ss., 102 y ss.) al estimar que esta institución no afecta a la libertad y por la necesidad de interpretar restrictivamente lo que ha de regularse por ley orgánica, añadiendo que las manifestaciones de la 
un rango que no cumple, por su carácter preconstitucional y decimonónico, la Ley de Indulto. Esta deficiencia no fue subsanada por la reiterada reforma de 1988, lo que da lugar a la curiosa situación de que la ley que permite, a través del indulto, no solo dejar sin efecto todo o parte de una pena, sino también conmutarla por otra o suspenderla tiene un rango inferior -ley ordinaria - a aquella en virtud de la cual se ha fijado judicialmente la pena en el caso concreto — ley orgánica—, infringiéndose así el derecho fundamental a la legalidad penal.

Así pues, la LI no solo no satisface las exigencias de rango de la legalidad formal en la concesión de indultos, sino que tampoco satisface las exigencias de la legalidad material, al incumplir los requisitos de taxatividad y certeza de la ley penal ${ }^{39}$.

Al regular el indulto total el art. 11 de la LI establece que «El indulto total se otorgará a los penados tan solo en el caso de existir a su favor razones de justicia, equidad o utilidad pública, a juicio del Tribunal sentenciador». Sin embargo, estos criterios son tan amplios y vagos que dejan un margen casi ilimitado a la decisión del poder ejecutivo en la concesión o denegación de los indultos totales. Pero es que, además, los indultos parciales o las conmutaciones de penas, que son los más frecuentemente concedidos, no están sometidos, ni tan siquiera, a criterio alguno para su concesión, como se expondrá más adelante ${ }^{40}$.

\section{PROHIBICIÓN DE ARBITRARIEDAD}

La ausencia, como se acaba de ver, de criterios taxativos para acordar el indulto convierten a esta institución en una puerta abierta a la arbitrariedad en su concesión o denegación, lo que prohíbe el art. 9.3 de la CE en la actuación de cualquiera de los poderes públicos ${ }^{41}$. A esto habría que añadir la pro-

gracia no suponen una derogación de la norma, sino una excepción parcial, de mayor o menor amplitud, a la efectividad de la misma.

39 Para Aguado Renedo (2001: 157 y ss.), el indulto presenta «el obstáculo, imposible de superar, de compatibilizar esa atribución con la estricta sumisión [...] a la ley, principio este que se encuentra en el mismo núcleo del Estado de Derecho».

40[ En este sentido, Espina Ramos (2001: 2) llama la atención de que con los indultos se consagra «[...] un auténtico ámbito, no ya de discrecionalidad, sino de cuasi arbitrariedad $[\ldots] »$.

41 Vid. Sánchez-Vera y Gómez-Trelles (2008: 9). Significativas también son las palabras del jurista decimonónico Pacheco Gutiérrez Calderón (1836: 250 y ss.), el cual, al defender y definir el derecho de gracia como «[...] esa arbitrariedad constituida en derecho y prerrogativa de la Corona, y ejercida como todas ellas bajo la garantía de 
pia naturaleza del indulto como un poder graciable; incompatible, por ello, con el establecimiento de criterios reglados, de sujeción a límites en su concesión o de control jurisdiccional en el otorgamiento o no de este, por más que desde la Doctrina, sobre todo administrativista, se intente subsanar tal contradicción como se verá a continuación.

El indulto o es graciable o es otra cosa, lo que se aviene mal con la seguridad jurídica, cuya ausencia o menoscabo tiene consecuencias funestas especialmente en una rama del Ordenamiento Jurídico como el derecho penal, la cual es la más exigente en lo relativo no solo a la taxatividad requerida a sus normas, sino también en lo que respecta a la exigencia de motivación de sus resoluciones.

En concreto, el art. 120.2 de la CE establece que «las sentencias serán siempre motivadas y se pronunciarán en audiencia pública» ${ }^{42}$. Una declaración que se encuentra especialmente desarrollada, en lo que se refiere a la determinación de las penas, en el art. 72 del Código Penal, al disponer que: «Los jueces o tribunales, en la aplicación de la pena, con arreglo a las normas contenidas en este capítulo, razonarán en la sentencia el grado y extensión concreta de la impuesta». Esta exigencia de argumentación es tan esencial ${ }^{43}$ que su ausencia mo-

Ministros responsables [...] institución altamente útil en el interés de la Justicia y del Estado [...] entregársela a los Tribunales sería volver atrás en todo los adelantos [...] los Tribunales no deben dispensar del cumplimiento de las leyes [...]». Por su parte, Orts Berenguer; González Cussac (2004: 206) estiman que las manifestaciones del derecho de gracia suponen un ejercicio arbitrario del poder que choca frontalmente con el principio de legalidad penal.

42 Vid. SSTTCC 108/2001, de 23 de abril, FJ 3; 20/2003, de 10 de febrero, FJ 5; 136/2003, de 30 de junio, FJ 3; 11/2004, de 9 de febrero, FJ 2; 170/2004, de 18 de octubre, FJ 2 o STS 71/2011, de 4 de febrero, FJ Segundo. Significativo resulta lo expresado en el FJ Segundo del ATS de 9 de octubre de 2012, el cual califica al indulto como «Herencia del absolutismo, al fin y al cabo, de no fácil encaje, en principio, en un ordenamiento constitucional como el español vigente, presidido por el imperativo de sujeción al derecho de todos los poderes, tanto en el orden procedimental como sustancial de sus actos; y, en consecuencia, por el deber de dar pública cuenta del porqué de ellos. Un deber especialmente reforzado en su intensidad, cuando se trata de resoluciones jurisdiccionales, más aún si de sentencias de condena; que, paradójicamente, pueden luego, como en el caso, hacerse vanas sin que conste ninguna razón estimable, en el ejercicio de una discrecionalidad política, más bien arbitrio, no vinculada e incontrolable».

43 Este precepto se introdujo debido a la falta de motivación en el proceso de individualización de la pena impuesta en la que incurrían muchas sentencias; vid. Silva Sánchez (2007): 3 y ss. 
tivaría, según los casos, la nulidad de la sentencia, la reducción al mínimo legal de las penas impuestas o la concesión del amparo ${ }^{44}$. Este panorama se completa con la jurisprudencia desarrollada a partir de los Acuerdos del Pleno no jurisdiccional del Tribunal Supremo sobre el principio acusatorio ${ }^{45}$.

La doble exigencia de argumentación y publicidad de las resoluciones judiciales contrasta con la ausencia de transparencia y publicidad del procedimiento de concesión de los indultos, así como con la falta de la más elemental motivación en los Reales Decretos del Gobierno de turno al concederlos. Y esto es así pese a que mediante ellos se va a extinguir, total o parcialmente, la responsabilidad penal que los jueces y tribunales probaron, argumentaron y sentenciaron, con un esfuerzo superior a la media en muchos casos de corrupción, tras un proceso público con todas las garantías ${ }^{46}$.

Si bien en la redacción originaria de la LI de 1870 el art. 30 establecía que la concesión del indulto se haría en decreto motivado y acordado por el Consejo de Ministros, la reforma llevada a cabo por la Ley 1/1988, de 14 de enero suprimió, en pleno régimen democrático, la exigencia de tal motivación. Por lo tanto, no solo no existe ya una exigencia expresa de argumentación alguna, sino que los términos que se utilizan en la LI para referirse al informe que ha de emitir el Tribunal sentenciador para otorgar el indulto total son tan vagos que cabría cualquier solución (art. $11 \mathrm{LI}$ ).

En definitiva, la argumentación o motivación que se contiene en los Reales Decretos de concesión de indultos se mueven entre la inexistencia, la desconcertante concisión ${ }^{47}$, o cuando no, se hace uso de los más peregrinos argumentos, equivalentes por ello a la ausencia de toda motivación ${ }^{48}$.

44 Vid. SSTS 2-12-2003 o STS 1746/2014, de 8 de abril, «[...] las exigencias de motivación (arts. 24.1 y 120.3 CE), reforzada cuando se trata de restricción de derechos fundamentales, imponen que no sea suficiente la intervención de un juez, sino que es exigible que tal intervención esté razonada y justificada de forma expresa y suficiente»; SSTTCC 76/2007, 16 de abril, FJ 7; 108/2005, de 9 de mayo, FJ 2, y 123/2005, de 12 de mayo, FFJJ 3, 4 y 5.

45 Acuerdos del Pleno no Jurisdiccional del Tribunal Supremo 1/2007, de 27 de noviembre, aclaratorio del previo de 20 de diciembre de 2006 y SSTS 655/2014, de 15 de octubre y 619/2013, de 5 de julio, entre otras.

46 Manzanares Samaniego (2010: 957) califica gráficamente al indulto de «vaciado del fallo condenatorio de un sentencia elaborada, dictada y publicada [...]».

47 Así, por ejemplo, en el indulto del núm. 2 del Banco de Santander, el Gobierno utilizó como todo argumento que «era razonable» (BOE núm. 297, de 10-12-2011).

48 Como pone de manifiesto, Llorca Ortega (2003: 90) «Ante el derecho de gracia, uno lamenta las corruptelas y abusos que, a mi juicio y con más frecuencia que la deseada, afloran en su proposición, tramitación u otorgamiento». Vid. infra apartado 5 in fine. 
La STS 13/2013, de 20-11 de la Sala de lo Contencioso-Administrativo en Pleno (Ponente: Fernández Valverde), constituye un punto de inflexión en la necesidad de motivación de los indultos por el gobierno, anulando el que había sido concedido ${ }^{49}$.

En el citado indulto, el cual contó con los informes negativos del Ministerio Fiscal y del Tribunal Sentenciador, y favorable del centro penitenciario, se utilizaba, como única argumentación la siguiente: «[...] visto el expediente de indulto [...] en el que se han considerado los informes del Tribunal sentenciador y del Ministerio Fiscal, a propuesta del Ministro de Justicia y previa deliberación del Consejo de Ministros».

Esta Sentencia, que contó con numerosos votos particulares, intenta frenar el ejercicio de la arbitrariedad en materia de concesión de indultos por parte del Gobierno, si bien, como se verá, dada la esencia de esta institución, de manera más estética, coyuntural y limitada que efectiva, ya que la concesión de los indultos no constituye actividad administrativa a los efectos del art. 106 de la CE y, por tanto, no estaría sujeta al control de la jurisdicción contenciosa administrativa ${ }^{50}$.

La Sentencia distingue tres ámbitos en las resoluciones de indulto del gobierno:

a) El núcleo esencial de la gracia que comprende la decisión misma de conceder o no el indulto.

b) La observancia por parte del Gobierno de los requisitos formales en su concesión o, lo que es igual, el control de los elementos reglados de los actos del gobierno, cualquiera que sea su naturaleza (art. 2.c) de la Ley 29/1998, de la Jurisdicción Contenciosa-Administrativa].

c) La observancia de las razones de justicia, equidad o utilidad pública, exigidas legalmente.

Pues bien, únicamente con relación a esta última cabría realizar el control de la arbitrariedad, pues, como esgrime el Alto Tribunal, si el legislador ha establecido la obligación de seguir un procedimiento para la concesión o denegación de los indultos que ha de materializarse en un expediente adminis-

49 Este controvertido indulto se concedió a un conductor suicida (supra nota 5), condenado a trece años de prisión, conmutándole tal pena por dos años de multa, a razón de una cuota de seis euros diarios, a condición de que abonara las responsabilidades civiles fijadas en la sentencia y no volviera a cometer ningún delito doloso en el plazo de cinco años.

50 Linde Paniagua (2000: 168 y ss.). 
trativo y, si el mismo legislador exige "que consten siempre las razones que le movieron a ejercer la prerrogativa constitucional», obvio es llegar a la conclusión de que el legislador ha pretendido que de esa tramitación documentada se desprendan las tan citadas razones de justicia, equidad o utilidad pública legalmente exigibles, pues de otra forma la absoluta inutilidad del expediente de indulto resultaría clamorosa.

Como consecuencia de lo expuesto, el fallo de la reiterada STS anula el indulto, recurrido por la familia del conductor fallecido, y devuelve el expediente "al órgano de procedencia, para que, en su caso y si a bien lo tiene, adopte su decisión de indultar - ya que el Tribunal Supremo no puede revisar la decisión de indultar - en los términos expresados en el texto de la presente sentencia.

Esta Sentencia resulta no obstante criticable por las siguientes razones:

a) El indulto no es un acto discrecional, sino un auténtico acto graciable ${ }^{51}$. Esta diferenciación es importante, pues mientras que en los actos discrecionales o en los conceptos jurídicos indeterminados cabe señalar una única solución justa o factible, en el acto graciable cualquier solución — conceder o no el indulto- es viable y no puede ser sometida, en último extremo, a ningún control ${ }^{52}$, lo que es reconocido por la sentencia.

b) Olvida la reiterada sentencia que la reforma de la LI de 1988 derogó el requisito de la argumentación para los indultos parciales o por conmutación, como el anulado, no estando el Gobierno obligado a realizar motivación alguna, como se puso de manifiesto más arriba (apdo. 3).

51 Como pone de manifiesto Queralt Jiménez (2014: 2), es un contrasentido proponer que el indulto sea motivado - lo que es incompatible con el derecho de gracia: un derecho de gracia reglado no es derecho de gracia- - y controlado además por los tribunales de lo contencioso administrativo. En el mismo sentido se pronuncia la Consulta de la FGE de 19 de julio de 1994, quien afirma el carácter excepcional del indulto y recalca que no se trata de un derecho, sino de una "gracia». En contra: Perez Francesch; Domínguez García (2002: 29) consideran que «aunque el indulto es discrecional en su otorgamiento contiene elementos reglados que permiten y exigen el control jurisdiccional»; para Sequeros Sazatornil (2005: 966 y 968), el indulto no puede ser concebido como un acto político, sino como un acto administrativo sui generis de naturaleza gubernamental, basándose en que se pueden controlar todos los presupuestos de tal acto.

52 García De Enterría (1962: 184 y ss. y n. 53) los caracteriza como aquellos en los que se puede actuar «sin límite legal ninguno [...] puesto que no existe medio técnico ninguno, ni de imponerle [...] límites legales, ni de exigirle el respeto a esos derechos hipotéticamente atropellados». 
c) Aun acudiendo por una interpretación extensiva a los criterios establecidos para el indulto total, estos son tan amplios y vagos que difícilmente pueden ser considerados como mecanismos de control de la decisión graciable, ya que bajo estos podrían argumentarse tanto la denegación como la concesión de un indulto en la inmensa mayoría de los casos.

En definitiva, el denominado control jurisdiccional del indulto es más un artilugio estético y retórico que un control efectivo, pues, como ha reconocido la propia doctrina constitucionalista, se ve dificultado, además, por obstáculos de carácter técnico: la ausencia de un acto recurrible si se deniega la gracia y la falta de un interés legítimo por parte del condenado si se otorga ${ }^{53}$. Sin olvidar el problema de las garantías de defensa en lo relativo a la posibilidad del indultado de recurrir la sentencia por la que se le impuso la pena luego indultada ${ }^{54}$. A todo esto habría que añadir el pernicioso salto de jurisdicciones que genera el indulto, pues lo que es una cuestión penal acaba convirtiéndose, por el recurso ejercido contra el real decreto de indulto, en una cuestión contenciosaadministrativa, lo que convierte a esta institución, como ya sucedió en Italia, en «una cuarta instancia del proceso penal, conducida por autoridad no jurisdiccional, con criterios absolutamente discrecionales y sin ninguna garantía formal reconocida al sujeto solicitante» ${ }^{55}$.

53 Vid. para un resumen de la jurisprudencia sobre la legitimación en casos de intereses difusos, STS 6. ${ }^{\text {a }}$ de 8 de junio de 2015.

54 Lozano Cutanda (1991: 1050-1051) destaca como en el caso de que no se otorgue el indulto, la ley ni tan siquiera prescribe la notificación al solicitante de la denegación de su petición; Roldán Barbero (1991): 507, hacía ya notar como mientras que en la libertad condicional, la redención de penas por el trabajo, a lo que había que añadir las progresiones en grado o la concesión de permisos de salida, son medidas resueltas por el juez de Vigilancia Penitenciaria, esto es, por el poder judicial en el ejercicio de ejecutar lo juzgado, la concesión del indulto penitenciario del art. 257.b) del Reglamento Penitenciario será competencia del Gobierno y, por tanto, no estará sometido a recurso jurisdiccional penal; vid. STC 797/1987, de 27 de mayo, en el caso de un indulto total.

55 Así, Zagrebelsky (1974: 222). Por su parte, Navarro Villanueva (2009: 251) considera que el control judicial de los aspectos procedimentales del indulto lo ha de realizar el tribunal sentenciador, esto es, el del orden penal, no uno del orden contencioso-administrativo, y siguiendo a Aguado Renedo (2001: 190 y ss.) concluye que el control de los aspectos de fondo de la gracia debería de corresponder al Tribunal Constitucional; en análogo sentido, Sequeros Sazatornil (2005: 966 y 968), al estimar que así se evitaría que el indulto devenga en un acto injusto o arbitrario por falta de la debida motivación 
Pero junto a esta arbitrariedad, que podríamos denominar material, pasa desapercibida otra: la arbitrariedad temporal. Esto es, la que afecta al tiempo que se toma el Gobierno para conceder o denegar los indultos. La única prescripción existente sobre este particular en la LI es la que se introdujo en el art. 28, tras la reforma llevada a cabo por la reiterada Ley 1/1988. Según dispone el mencionado precepto, las solicitudes de indulto en las que el tribunal sentenciador, el condenado y el fiscal estuvieran de acuerdo se tramitarían «de forma preferente», sin más especificaciones. No obstante, aunque no lo recoja la Ley, no habría que olvidar que también tendrán prioridad los indultos calificados, según el criterio del gobierno de turno, «de especial urgencia o importancia».

Con posterioridad, el art. 6.1 del Real Decreto 1879/1994, de 16 de septiembre, por el que se aprueban determinadas normas procedimentales en materia de Justicia e Interior (modificado por el Real Decreto de 1 de agosto de 1997), estableció que «Los procedimientos a los que dé lugar el ejercicio del derecho de gracia habrán de ser resueltos en el plazo máximo de un año, pudiendo entenderse desestimadas las solicitudes cuando no haya recaído resolución expresa en el indicado plazo» ${ }^{56}$. Esto es, no se trata de un silencio negativo, sino de un silencio de suspense, de tal manera que, transcurrido dicho plazo, al solicitante podría concedérsele todavía el indulto. Otra prueba más del carácter graciable del indulto.

Además, este silencio de suspense serviría como un período de tiempo para buscar, estratégicamente, un momento socioeconómico o político más propicio en el que la concesión del indulto pase desapercibida, o bien tenga un menor coste político, lo que puede resultar muy útil para indultar a condenados por delitos de corrupción.

Tampoco se recoge en la LI disposición alguna sobre la denegación del indulto. De hecho, el capítulo III de la LI lleva por rúbrica: «Del procedimiento para solicitar y conceder la gracia del indulto». En consecuencia, si el indulto es denegado a una persona, nada se opone a que esta solicitud pueda reiterarse una y otra vez. Lo que ciertamente da también mucho juego en los casos de delitos de corrupción, al igual que el «silencio de suspense» ${ }^{57}$.

56 Precepto este que, como afirma García Mahamut (2004): 264, genera gran inseguridad jurídica, ya que no dice expresamente que se entenderá denegado, sino que "pudiera entenderse», considerando además que este artículo no será de aplicación en los supuestos del art. 4.4. del Código Penal.

57 Sí lo hacía el Borrador del Anteproyecto de Nueva Ley de Indulto, de 18 de julio de 2005, el cual establecía que debían transcurrir dos años, a contar desde la fecha de la previa denegación, para formular una nueva petición de indulto. 
La media de tiempo en la concesión de un indulto es de dos años y medio, aproximadamente, pero esta duración varía mucho según el tipo de delito y, sobre todo, el caso concreto. Así, los indultos por delitos contra la ordenación del territorio y el medio ambiente son los más raudos (en torno a poco más de año y medio). También destacan los dos años de media para los indultados condenados por delitos contra los derechos de los trabajadores.

En el otro extremo se encontrarían, con una media de más de tres años, los delitos contra la Administración Pública, una categoría que incluye los casos de cohecho, prevaricación, malversaciones o fraudes. Esta duración se debe, entre otras razones, a que en tales casos la prudencia política aconseja, en ocasiones, dejar pasar un cierto período de tiempo para contar con el factor del olvido de los medios de comunicación y por ende de la opinión pública. Sin olvidar, además, que en estos casos se suelen interponer todos los recursos posibles, lo que incrementa la sensación de tardanza en la concesión del indulto desde que se dicta la sentencia definitiva pero no firme.

Sin embargo, los períodos expuestos son puramente orientativos, ya que lo determinante en el indulto es siempre el caso concreto. A este respecto existen supuestos de sorprendente celeridad como un caso de prevaricación en el que tras tan solo 123 días después de la sentencia firme, se concede el indulto ${ }^{58}$; o los 147 días que tardaron en ser concedidos los indultos a los condenados implicados en el GAL por delito de malversación de caudales públicos y/o secuestro (BOE de 22-1-1999).

\section{PRINCIPIO DE IGUALDAD}

Afirmaba Concepción Arenal que:

La injusticia de las leyes crueles no se evita sustrayendo a su acción algunos pocos privilegiados por medio del derecho de gracia, sino suprimiéndolas para

58 En concreto, un jefe de servicio de la Administración autonómica en Castilla y León condenado por sentencia firme el 10 de mayo de 1999 por prevaricación a la pena de siete años de inhabilitación especial para empleo y cargo público que ostentaba al tiempo de la comisión de los hechos, así como para obtener otro cargo o empleo público de similar contenido, esto es, cualquier otra jefatura de servicio o sección o cargo similar que implique responsabilidad y/o mando funcionarial, fue indultado por RD 1444/1999, de 10 de septiembre (BOE núm. 236, de 2-10-1999), dentro del mismo año. En 2003 esta persona estaba incorporada a la política, presidiendo ponencias o firmando disposiciones como jefe de servicio territorial de la Consejería de Medio Ambiente de Castilla y León. Lo curioso de este caso es que las sanciones administrativas disciplinarias que se derivaban de la comisión del delito no desaparecían por el indulto. 
todos [...] no hay nada de jurídico en la facultad de anular en unos casos los fallos de los tribunales dados conforme a la ley, y dejar que se ejecuten en otros. Decir que la dureza de las penas hace preciso el poder de aminorarlas arbitrariamente, es confesar la necesidad de modificar la legislación penal ${ }^{59}$.

La infracción del principio de igualdad es evidente en la concesión de los indultos, ya que ni todos los condenados lo solicitan, ni a todos los condenados que lo solicitan, con similares condenas y circunstancias, se les concede. Este dato se hace especialmente visible en los casos de delitos de corrupción en los que los vaivenes de la vida política convierten el otorgamiento de un indulto en una tómbola que gira al ritmo de la coyuntura política ${ }^{60}$.

Pero es que, además, aun concediéndose el indulto, por el mismo delito y con las mismas circunstancias, a unos condenados se les otorgará de forma total, los menos, mientras que a otros se les podrá conmutar las penas impuestas por otras o se les concederá el indulto parcial ${ }^{61}$.

Resulta manifiestamente insatisfactorio que, si un problema penal es general, como sucede en los supuestos de desproporción de penas, delitos anacrónicos, o tipos supuestamente inconstitucionales ${ }^{62}$, estos se pretendan solventar a través de una figura de funcionamiento particular como el indulto, en lugar de acudir a una reforma legislativa.

El principio de legalidad tanto en el ámbito material penal, anudado a la tipicidad penal ${ }^{63}$, como cuando opera en el proceso penal constituye una garantía no solo de la seguridad jurídica, sino también de la igualdad de todos los ciudadanos ante la ley, las cuales resultan conculcadas por el principio de oportunidad, en el ámbito del proceso penal ${ }^{64}$, y por el indulto, en el ámbito de la ejecución de la pena impuesta.

59 Arenal Ponte (1820-1893: 1).

60 Ilustrativamente, sirvan estas palabras de Fraga Iribarne (Diario de Sesiones del Congreso de los Diputados - Comisión de Asuntos Constitucionales y Libertades Públicas- de 30-5-1978, núm. 76, p. 2766): «La concesión de los efectos del derecho de gracia evidentemente tiene que ver no solo con problemas de justicia, sino con problemas políticos en muchos casos».

61 Ya ponía de manifiesto Rubio Llorente (2009: 1) la dificultad de conciliar el principio de igualdad con el ejercicio del derecho de gracia a través de los indultos concedidos por el gobierno, propugnando una interpretación restrictiva de la Ley que los regula.

62 Vid. nota 22.

63 Ya desde Beling (1906: 21 y ss, 159 y ss.).

64 Vid. por todos: Armenta Deu (1995: 461). 


\section{ESTADO ACONFESIONAL Y JUSTICIA PENAL}

El proceso de selección y configuración de los bienes jurídico-penales, así como el de tipificación de conductas se halla inspirado por un conjunto de valores judeocristianos, afirmación esta que puede hacerse extensible a cualquier estado del mundo occidental. Sin embargo, esto no justifica ni tiene nada que ver con que, directa o indirectamente, se siga conectando el derecho penal con el ejercicio de una justicia entre consuetudinaria y divina, heredera de un modelo de estado absolutista y confesional.

En este sentido menoscaban la aconfesionalidad del Estado en el ejercicio de la justicia penal (arts. 1.1 y 16.2 CE): las solicitudes de indulto por parte de las hermandades y cofradías de Semana Santa de las diferentes regiones de España $^{65}$; la concesión de indultos, aprovechando tal festividad religiosa ${ }^{66}$; o el acudir a motivos religiosos para argumentar los reales decretos de concesión de los indultos ${ }^{67}$. En concreto, en la comparecencia del ministro de Justicia de 1 de diciembre de 2000, con ocasión de los 1443 indultos concedidos $^{68}$, el citado

65 En la Semana Santa de 2014 los indultos ascendieron a 21, mientras que en 2013 fueron 16.

66 Así, en el BOE de 12 de abril de 2014 se publicaban dentro del apartado «Otras Disposiciones» 19 indultos a solicitud de diferentes Hermandades y Cofradías, v. gr.: Hermandad de Jesús Cautivo (Oviedo); Real Hermandad de Jesús Atado a la Columna y de Ntra. Sra. de La Esperanza (Teruel); Cofradía Jesús El Rico (Málaga); Cofradía de Nuestra Señora de La Piedad y del Santo Sepulcro (Zaragoza); Cofradía Penitencial de Nuestra Señora de La Piedad (Valladolid); Hermandad de Jesús Nazareno (Ponferrada, León); Cofradía de Jesús en La Columna del Cabañal (Valencia); Hermandad de Nuestro Padre Jesús Nazareno y María Santísima de La Victoria en su Pena y Dolor (Baza, Granada); Ilustre Hermandad del Santísimo Sacramento y Cofradía de Nazarenos de Jesús del Perdón, Cristo del Amor en Su Prendimiento, María Santísima de La Esperanza, San Pedro y San Juan Apóstoles (Jaén); Cofradía del Santísimo Cristo del Perdón (Elche, Alicante); Cofradía del Perdón (Palencia); Cofradía Nuestra Señora de La Soledad y de Santiago (Burgos), entre otras.

67 En la misma línea se incluiría la pervivencia consuetudinaria existente, desde supuestamente 1759, en la época del reinado de Carlos III, de indultar a un preso a solicitud de la «Real, Muy Excelentísima, Muy Ilustre y Venerable Cofradía de Cristo y Procesión de Nuestro Padre Jesús Nazareno, titulado «El Rico» y María Santísima del Amor», siendo casi siempre otorgado; sobre los orígenes históricos de esta Cofradía y de la concesión de indultos a solicitud de la misma, Vid. Mapelli López (1997: 62 y ss).

68 Sesión de 13-12-2000 de la Comisión de Justicia e Interior (Diario de Sesiones. Congreso de los Diputados, Comisiones, Justicia e Interior, VII Legislatura, núm. 121, p. 3500). 
ministro alegó, como razones de tal masiva concesión, que era «una petición papal como motivo del Año Santo» o que tales indultos se concedieron porque «se acababa el milenio». Argumentos estos que recuerdan a los recogidos en los denominados indultos generales del régimen predemocrático ${ }^{69}$.

Incluso siendo España un estado aconfesional débil, la aconfesionalidad significa prohibición de confusión entre funciones religiosas y funciones estatales, esto es, las confesiones no pueden obligar al Estado a inspirar su legislación de acuerdo a sus valores propios, ni tampoco sus resoluciones como sucede en algunas modalidades de indulto ${ }^{70}$.

\section{PROPORCIONALIDAD DE LAS PENAS}

Este es uno de los principales argumentos aducidos a la hora de justificar la pervivencia del indulto en los sistemas democráticos de derecho. Pero lo cierto es que, en los casos de penas desproporcionadas, la dinámica del indulto lejos de resolver el problema lo perpetua; y genera para el poder judicial un círculo perverso en el que este se hallará involuntariamente inmerso.

La dinámica de los hechos suele ser, en términos generales, siempre la misma. En primer lugar, el poder ejecutivo, quien de forma protagonista lidera la iniciativa legislativa, crea el problema con la presentación de reformas penales que conculcan el principio de proporcionalidad. Pero, sabedor este de que con ello satisface un populismo punitivo que le otorgará rédito electoral, eleva al Congreso un proyecto de ley orgánica penal, curiosamente casi siempre en vísperas de procesos lectorales o en épocas de pérdida de popularidad.

Secundado por su mayoría parlamentaria — sobre todo cuando es absoluta, sea o no monocolor - la ley penal desproporcionada resulta aprobada. En la mentalidad cortoplacista que caracteriza a la clase política, el ejecutivo que impulsó la aprobación de la ley penal desproporcionada sabe que, sigan o no en el poder, las críticas se volverán fundamentalmente contra el poder judicial que tendrá que aplicarla (arts. 4 CP y 1.7 CC).

Así las cosas, la ley penal desproporcionada entra en vigor y, como consecuencia de su aplicación, afloran sus efectos perversos e insatisfactorios. El sistema democrático de derecho cuenta con recursos para luchar contra la ley desproporcionada y, en puridad, lo que procedería sería: una reforma legislativa; la presentación de un recurso de inconstitucionalidad por otros grupos

69 Vid. supra nota 3.

70 Para otras manifestaciones del menoscabo de la laicidad en la Administración de Justicia, vid. Rey Martínez (2012: 408 y n. 52). 
parlamentarios; o la presentación de una cuestión de inconstitucionalidad por los órganos judiciales.

Sin embargo, como se verá, será difícil que alguno de tales mecanismos se active. En el primer lugar, acometer la reforma legislativa será difícil porque proponer reformas penales a la baja no suelen ser electoralmente rentable.

En cuanto a la presentación de un recurso de inconstitucionalidad por los grupos de la oposición que pretenden acceder al poder, por las mismas razones, sobre todo cuando existe una alternancia de partidos políticos, tampoco se producirá, ya que ninguna opción política, ni siquiera las de izquierda, quiere aparecer ante la opinión pública como floja, liderando proyectos de soft law. Esto sucederá singularmente cuando se trate de materias tan sensibles como: los delitos de terrorismo, contra la libertad e indemnidad sexuales, tráfico de drogas o de corrupción ${ }^{71}$.

Por último, el planteamiento de cuestiones de inconstitucionalidad tampoco será frecuente porque los jueces, abrumados por el exceso causas pendientes, afrontan el planteamiento de una cuestión de inconstitucionalidad como una sobrecarga de trabajo; o, cuando no, corren el peligro de verse significados políticamente, según la naturaleza de aquella, por lo que terminan viendo más factible hacer uso de la vía del apartado 3 del art. 4 del Código Penal, generalmente además, a través de las organizaciones judiciales ${ }^{72}$.

En definitiva, aunque el sistema democrático de derecho tiene previstas vías para dar solución al problema de los delitos con penas desproporcionadas, su no articulación hace aparecer falsamente al indulto como la única solución posible, lo que produce un triple efecto perverso:

71 Significativa resulta la Exposición de Motivos de la LO 5/2010, al justificar la reducción de penas en materia de tráfico de drogas, expresa que «[...] se acoge la previsión contenida en el Acuerdo del Pleno no Jurisdiccional de la Sala 2. ${ }^{\text {a }}$ del Tribunal Supremo, de 25 de octubre de 2005, en relación con la posibilidad de reducir la pena respecto de supuestos de escasa entidad, siempre que no concurra ninguna de las circunstancias recogidas en los arts. 369 bis, 370 y siguientes». Esto es, el ejecutivo no es el que insta la moderación de penas, sino que se limita a seguir los criterios que le indica el poder judicial, y que también venían siendo requeridos por la doctrina, Vid. entre otros: Fakhouri Gómez (2010: 458 y 459); Gallego Soler (2011: 805 y 806).

72 En concreto, según dispone el apartado 3 del citado precepto, un juez o tribunal: «Del mismo modo acudirá al Gobierno exponiendo lo conveniente sobre la derogación o modificación del precepto o la concesión del indulto, sin perjuicio de ejecutar desde luego la sentencia, cuando de la rigurosa aplicación de las disposiciones de la Ley resulte penada una acción u omisión que, a juicio del Juez o Tribunal, no debiera serlo, o cuando la pena sea notablemente excesiva, atendidos el mal causado por la infracción y las circunstancias personales del reo». 
a) desprestigia al sistema penal, tanto en el ámbito sustantivo como en el procesal;

b) provoca un despilfarro de recursos públicos — personales y materiales- en el seno del poder judicial, ya que el indulto se otorga siempre sobre sentencias firmes, esto es, cuando ya se han celebrado un procedimiento, desarrollado en una o varias instancias, lo que es siempre costoso para las arcas públicas, sobre todo cuando se tratan de delitos de corrupción;

c) da soluciones particulares a un problema general: la desproporción de la ley penal ${ }^{73}$.

\section{FINES DE LA PENA}

El indulto, singularmente en las condenas por delitos de corrupción, afecta de manera sensible a lo que se ha dado en llamar restauración de la vigencia de la norma conculcada ${ }^{74}$, en cuanto que toda clemencia irrumpe de forma abrupta en la estabilización que se pretende con la imposición de la pena, especialmente en casos de corrupción.

Pero el indulto no solo conculca la controvertida prevención general positiva, sino también la negativa en aquellos casos en los que la mera proximidad al poder del solicitante del indulto o de sus abogados, la necesidad de vaciar las prisiones, o por cualquier otro criterio ajeno a la Administración de Justicia, se procede a la derogación de la vigencia de la norma para un caso concreto $^{75}$. De

73 Como pone de manifiesto Lascurain Sánchez (1998: 174 y ss.): «[...] en preceptos que imponen gravosas prevenciones a amplios sectores de la población-, ello redundará, en garantía de quien pueda resultar penado, en los perjuicios que irroga la norma y empujará hacia abajo la pena imponible que quiera resultar internamente proporcionada»; uno de los mecanismos que se utilizan para empujar la pena hacia abajo serán los indultos parciales o las conmutaciones de penas previstas en estos.

74 Álvarez García (2000: 611), considera que dentro de la prevención general negativa se hallaría incluido el aspecto positivo de la confirmación de la vigencia de la norma; por su parte, Alcácer Guirao (1989: 5 y ss.) señala que «La prevención general positiva no busca producir efectos preventivos a través de la intimidación, sino que tal prevención se busca mediatamente, a través de la pena impuesta, por medio de la estabilización de la conciencia jurídica colectiva y el restablecimiento del equilibrio psicosocial alterado por el delito»; Mir Puig (1986: 58) sostiene que, si bien no es lícito castigar para forjar conciencia jurídica, por progresiva que esta sea, si le parece adecuada al Estado social y democrático de derecho la función limitadora de la prevención general positiva; en análogo sentido, Sánchez-Vera Gómez Trelles (2008: 6 y ss. y n. 6).

75 En este sentido Dubois (1924: 309), ya llamaba la atención de cómo el indulto hacía surgir en la opinión pública la creencia de la inutilidad de la ley penal. 
esta manera, tras complicados procesos, la mayoría de las veces dilatados en el tiempo por su complejidad o por la sistemática intervención de las defensas, y una vez producida la condena por sentencia firme, casos de gran relevancia y trascendencia pública, como son los delitos de corrupción, quedan finalmente sin sanción penal por motivos diferentes a los ideales de justicia ${ }^{76}$.

Además, no habría que olvidar que el Tribunal Constitucional, a propósito del art. 25.2 de la CE, ha tenido ocasión de recordar que la pena es un castigo impuesto conforme al principio de culpabilidad y con una indudable incidencia sobre la prevención general ${ }^{77}$.

En la doctrina italiana, un país donde se aplicó y debatió ampliamente sobre el indulto en los años setenta, se denunciaba que las modalidades de gracia no hacían sino favorecer la criminalidad, sin ofrecer una alternativa que solucione el problema en las sociedades avanzadas, generando como reacción un autoritarismo punitivo que en nada ayuda a la estabilidad democrática y, por supuesto, supone un obstáculo a la racional reforma de la legislación penal $^{78}$.

Desde el punto de vista de la prevención especial, el indulto, sobre todo en el denominado masivo, para disminuir la población reclusa, difícilmente puede cumplir tal finalidad, ya que supondría un fracaso de la política criminal y penitenciaria del Gobierno que los concede. Internos que, con un adecuado tratamiento penitenciario, pudieron haber completado un ciclo profesional o formativo, haberse desintoxicado de las drogas o realizado cualquier otro tratamiento tendente a erradicar la causa que les trajo a prisión, verán tales fines truncados por obra y gracia del indulto desmasificador-economizador.

No son menos funestos los efectos del derecho de gracia en casos de condenados por delitos de corrupción, los cuales, desde el punto de vista de la prevención especial, perciben gracias al indulto que el sistema penal es un obstáculo vencible, y que la prisión no es un lugar para personas de cierto estatus económico, político o social, sino para la población marginada. Por todo ello, las posibilidades de comisión de nuevos delitos de corrupción, por sí o por personas interpuestas, son altas ${ }^{79}$. Desde un punto de vista de prevención

76 Vid. Espina Ramos (2001: 17).

77 Vid. entre otras, STC 163/2002, de 16 de septiembre, FJ 4; en sentido similar, SSTTCC 25/2000, de 31 de enero, FFJJ 3 y 7; 8/2001, de 15 de enero, FFJJ 2 y 3; 110/2003, de 16 de junio, FJ 4; 248/2004, de 20 de diciembre, FJ 4; 160/2012, de 20 de septiembre, FJ 3, a).

78 Por todos, Gemma (1973): 35 y ss.

79 En análogo sentido, Ortiz De Urbina (2012: 396 y ss.) pone de manifiesto, en relación con los delitos de corrupción, que los condenados por estos delitos perciben la 
general, el indulto imposibilitará preservar y reafirmar valores cívicos esenciales para el funcionamiento de cualquier estado democrático. Por lo que, en este ámbito delictivo, las relaciones entre prevención general y especial tiene que ser revisadas ${ }^{80}$.

Por lo que a la reinserción social se refiere, se suele argumentar que con el indulto esta se potencia en relación con las personas condenadas que ya están reinsertadas, de manera que la buena conducta durante el cumplimiento de la pena se tendría que ver compensada con el indulto. Sin embargo, tal argumento solo sería predicable de la ejecución tardía —a la que se hará referencia en el apartado siguiente- $y$, por tanto, no resulta convincente como argumentación general justificativa de la pervivencia del indulto ${ }^{81}$.

Por otro lado, habría que recordar que para supuestos de buena conducta penitenciaria ya están previstos los beneficios penitenciarios, incluida la libertad condicional, los cuales son un medio más adecuado para reducir el tiempo de privación de libertad por esta causa, siendo además su denegación recurrible jurisdiccionalmente, a diferencia de lo que sucede con la decisión misma de conceder o denegar el indulto ${ }^{82}$.

probabilidad de sanción como muy baja. Significativas resultan también las alegaciones esgrimidas en la solicitud del indulto de un famoso abogado y presidente de un club de fútbol, en la que se argumentaba que el condenado «puede ser más útil para la sociedad estando en libertad».

80 Luzón Peña (1979: 20) ya sostenía - lo que sería de especial relevancia en caso de delitos de corrupción - que la prevención general puede ser el único fin de la ejecución en aquellos casos límite en que no haya ninguna necesidad de prevención especial y, sin embargo, las exigencias de prevención general se opongan a renunciar a la ejecución; añadía este autor (Luzón Peña, 1991: 276-278) que en los casos de miembros de las clases sociales privilegiadas o acomodadas - a las que suelen pertenecer los sujetos activos de los delitos de corrupción— «podrá darse mucho más fácilmente la circunstancia de nula o menor necesidad preventivo-especial de pena o de que ésta sea incluso contraindicada, contraproducente para el sujeto: con lo que los sustitutivos penales les serán aplicados a estas personas preferentemente o con mucha mayor frecuencia [...] que a los sujetos pertenecientes a las clases inferiores». De otra opinión, Cardenal Montraveta (2015: 17). Para un análisis de este problema desde las denominadas «normas descriptivas», vid. Miró Llinares; Bautista Ortuño (2013: 14 y ss.)

81 Por contra, Muñoz Conde; García Arán (2010): 403, consideran que «desde un punto de vista político-criminal, el derecho de gracia pude ser utilizado como medio para conseguir la rehabilitación del condenado [...]».

82 En este sentido, Navarro Villanueva (2009: 237). Vid. también el art. 206 del Real Decreto 190/1996, de 9 de febrero, por el que se aprueba el Reglamento Penitenciario. 
Por último, no habría que olvidar la desconsideración o desatención que conlleva el indulto hacia las víctimas ${ }^{83}$, lo que no hay que circunscribir a los delitos contra bienes jurídico-penales individuales, sino que también tal efecto perverso se produce contra víctimas difusas o colectivas de los delitos de corrupción, ya que la recuperación de los activos públicos no suele guardar nunca proporción con los evadidos por los indultados.

\section{DILACIONES INDEBIDAS EN EL ENJUICIAMIENTO O EN LA EJECUCIÓN DE LAS PENAS}

Estas causas de disfunción del sistema penal son otros de los motivos clásicos para sostener la necesidad del mantenimiento de la institución del indulto. Es decir, aquellos supuestos en los que, por causas imputables a la Administración de Justicia, y siempre, lógicamente, que no proceda la prescripción del delito o de la pena, un caso es resuelto o su pena va ser ejecutada muchos años después de la comisión del delito o de ser dictada la sentencia firme, respectivamente ${ }^{84}$.

Por lo que se refiere a los enjuiciamientos tardíos, estos constituyen una conculcación del derecho a la tutela judicial efectiva para el imputado y a un proceso público con todas las garantías (art. $24 \mathrm{CE})^{85}$. De ahí que, tras la Reforma del Código Penal de 2010, se haya dado como solución, no sin cierta polémica desde el punto de vista de las víctimas, la atenuante de dilaciones indebidas ${ }^{86}$.

Esta atenuante, según viene entendiendo una jurisprudencia reiterada, se aplicará como genérica ${ }^{87}$, salvo que el tiempo de retraso sea significativo, esto

83 Corcoy Bidasolo (2012: 74) hace notar como el derecho de las víctimas se contrapone al derecho de los acusados, limitando los de aquellas con institutos como el indulto.

84 Este es el supuesto al que refiere el Tribunal Supremo el concepto de «utilidad pública» (art. 11 de la Ley de Indulto - indultos totales-). Sin embargo, el voto particular de Bacigalupo Zapater (STS de 6-7-1992) rechaza que el indulto, como decisión graciosa del ejecutivo, sea el que repare un derecho fundamental, al conculcar la separación de poderes.

85 Vid. la reciente STC 54/2014, de 10 de abril, FJ 4., en la que se señala, reiterando jurisprudencia anterior, los criterios objetivos para su determinación. Vid. por todos en la doctrina penal, Asúa Batarrita (2010: 171).

86 Ya en la STS de 11 de febrero de 1997 se consideraba que en tales casos se daba una vulneración del derecho recogido en el art. 24.2 de la CE.

87 Vid. SSTS 179/2015, de 20 de enero; o la 5534/2014, de 29 de diciembre. Sin embargo, no procederá su apreciación, STS 429/2012, de 21 de mayo, FJ Decimoquinto, cuando «los retrasos fueron debidos esencialmente a las peticiones realizadas por 
es, los supuestos que suelen ser objeto de indulto, en cuyo caso habrá de ser apreciada como muy cualificada ${ }^{88}$, lo que permitirá bajar la pena en el caso de delitos dolosos y siempre que no concurra ninguna agravante, hasta en dos grados (art. 66.1.2. ${ }^{\text {a }} \mathrm{CP}$ ). Esto dará lugar, a su vez, tratándose de penas privativas de libertad, a que la pena resultante por su escasa duración, se pueda (art. $80 \mathrm{CP}$, hasta dos años) o se tenga que suspender o sustituir (supuesto de penas resultantes inferiores a tres meses, art. 71.2 CP) ${ }^{89}$.

Además de todo lo anterior, también durante la tramitación del procedimiento la parte afectada por la dilación indebida puede interponer el correspondiente recurso, según la fase en la que aquel se halle, bien ante el órgano jurisdiccional que lo sustancia o ante su superior, a los efectos de dar al órgano judicial la posibilidad de reparar o evitar que aquella se produzca.

Por lo que se refiere a las dilaciones indebidas en la ejecución de la pena impuesta, este sigue siendo esgrimido como argumento de cierre para la pervivencia del indulto. Se considera en estos casos que, no habiendo el sujeto vuelto a delinquir, aquella infracción delictiva en la que se incurrió supuso para el sujeto en cuestión un acontecimiento desgraciado y puntual en su vida, de tal manera que, hallándose reinsertado con trabajo, y/o familia, no existe ya necesidad de ejecutar pena alguna ${ }^{90}$.

Sin embargo, también en este ámbito el indulto es una solución insatisfactoria, ya que la respuesta ha de buscarse en el ámbito del poder que creó el problema: el judicial ${ }^{91}$. A este respecto no hay que olvidar lo que a menudo se hace incluso por el propio poder judicial, que, por mandato constitucional

las defensas de los acusados», lo que es característico de los procesos penales por corrupción.

88 Aunque no existen unos límites fijos, en las sentencias de casación se suele aplicar la atenuante como muy cualificada en las causas que se celebran en un período que supera los ocho años de demora entre la imputación del acusado y la vista oral del juicio (SSTS 360/2014, de 21 de abril; 506/2002, de 21 de marzo); y más de cinco años entre los hechos y la sentencia definitiva, en las sentencias de apelación (SAP Islas

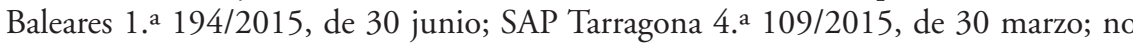
obstante lo aprecia a partir de tres años la SAP Madrid 30.a 464/2013, de 9 octubre).

89 Críticamente, Giménez García (2013: 42). En los casos de delitos imprudentes la ponderación dependerá del prudente arbitrio judicial, debidamente fundamentado (art. $72 \mathrm{CP}$ ).

90 En todo caso, como afirma García San Martín (2015: 97), el art. 4.4 del CP incurre en un contrasentido ya que nunca el cumplimiento de una pena puede dar lugar a la vulneración del derecho a un proceso sin dilaciones indebidas.

91 Es más, existen precedentes de este sistema en la Constitución de 1931, la cual atribuía al Tribunal Supremo la capacidad de indultar, excepción hecha de los delitos de 
(art. $117 \mathrm{CE}$ ) corresponde a los juzgados y tribunales no solo juzgar, sino también hacer ejecutar lo juzgado. Añade el apartado 4 del citado precepto constitucional que a estos les corresponden las funciones «[...] que expresamente les sean atribuidas por la ley en garantía de cualquier derecho». Así pues, se podría articular para los casos de ejecuciones tardías de penas un recurso extraordinario, de análoga factura al de revisión ${ }^{92}$, pero referido a la fase de ejecución de las penas, para aquellos supuestos en los que, sobrevenidamente, concurran causas que fueron de imposible previsión en el momento de dictarse sentencia firme y que, por tanto, constituirían un «hecho nuevo» en la ejecución de la pena impuesta ${ }^{93}$.

En definitiva, lo que es ciertamente cuestionable es querer reparar el derecho fundamental a un proceso penal —y/o de ejecución penal— sin dilaciones indebidas por la vía - excepcional y discrecional- del indulto, ya que este no sería más que una "esperanza de reparación»" o «una simple promesa de trato gracioso" ${ }^{95}$, cuyo proceso de concesión, paradójicamente, viene caracterizado, en muchas ocasiones, por una arbitraria dilación ${ }^{96}$.

\section{SUSPENSIÓN O SUSTITUCIÓN DE PENAS POR EL INDULTO}

El Tribunal Constitucional parte del principio de que «en un Estado de derecho las sentencias claman por ser cumplidas como exigencia implícita a la eficacia de la tutela judicial» (Autos del TC núms. 120/93, 198/95 y 199/95, entre otros). Esto es, la decisión de suspender la ejecución de las resoluciones judiciales es de carácter excepcional, pues el principio general en la materia es el que deriva del interés público que reclama que las resoluciones judiciales de carácter firme se cumplan ${ }^{97}$.

«extrema gravedad», los cuales quedaban bajo la competencia del presidente de la República.

92 Así Queralt Jiménez (2014: 3), quien estima que esta solución evita «sacar la sacrosantidad de la eficacia de lo juzgado fuera de su ámbito exclusivo: la jurisdicción, en este caso, penal».

93 Vid. Gómez Colomer (2001: 221 y ss.); por su parte, Gimeno Sendra y Díaz Martínez (2011: 523 y ss.) ponen de manifiesto que este recurso «tiene por objeto actuar el valor constitucional de la Justicia (art. 1.1 CE) y restablecer el derecho a la libertad del penado $[\ldots] »$.

94 Así, Navarro Villanueva (2009: 237).

95 Voto particular del magistrado Bacigalupo Zapater a la STS 444/1997, de 27 de enero.

96 Vid. supra apartado 3 (arbitrariedad temporal).

97 Como advierte Garberí Llobregat (2008: 214 ss.), el Tribunal Constitucional adopta un criterio sumamente restrictivo a la hora de considerar admisibles supuestos de 
En este sentido el art. 4.3 del Código Penal establece como regla general la ejecución inmediata de la sentencia, no obstante la petición de indulto; si bien se recogen en el art. 4.4 del Código Penal dos causas de suspensión de la pena en caso de solicitud de indulto: porque se pueda producir una vulneración del derecho a la tutela judicial efectiva — por ejemplo, dilaciones indebidas supra-; o porque se prevea una concesión favorable a la petición del indulto, de tal manera que la ejecución de la pena la haría ilusoria ${ }^{98}$.

Además, hay que tener en cuenta que art. 6 del citado Real Decreto 1879/94, de 16 de septiembre, establece, como se indicó más arriba, el plazo máximo de un año para la resolución del indulto, pudiendo entenderse desestimada la solicitud si no hubiera recaído resolución expresa en ese tiempo ${ }^{99}$, un plazo que, como se vio, tampoco se cumple.

Pues bien, la previsión de la suspensión de las penas en casos de solicitud de un indulto - la cual además no se circunscribe, como sucede en el art. 80, a las privativas de libertad- se puede ver distorsionada en sus efectos por la interferencia del instituto de la prescripción de la pena. A este respecto, la jurisprudencia del Tribunal Constitucional viene entendiendo que no se ha de aplicar el efecto interruptivo de la prescripción de la pena en los casos de suspensión de ejecución de la pena por la solicitud de un indulto, mientras se tramita el expediente del mismo y hasta que se produzca la denegación presunta —un año-, al no estar contemplada tal causa entre las que interrumpirían la prescripción de la pena, recogida en el art. 134 del Código Penal (SSTTCC 97/2010, 109/2013, 187/2013, 192/2013). Sin embargo, la LO $1 / 2015$, de 30 de marzo, por la que se modifica el Código Penal, introduce como novedad en el apartado 2 letra a) la suspensión de la prescripción de la

inejecución de resoluciones judiciales, las cuales han de estar basadas en una ley que, a su vez, ha de ser interpretada de la manera más favorable a la ejecución de la sentencia dictada ( $v$. gr. SSTTCC 18/1997, de 10 de febrero; 105/1997, de 2 de junio; $5 / 2003$, de 20 de enero, con cita de numerosas sentencias anteriores sobre este punto; o la 11/2008, de 21 de enero).

98 Tal serían los casos en los cuales por la lejana fecha en que ocurrieron los hechos y por ser las penas impuestas de corta duración, su inmediata ejecución podría hacer ilusoria una hipotética concesión del indulto. Por lo demás, este artículo supone una derogación tácita del art. 32 de la LI que establece que «La solicitud o propuesta de indulto no suspenderá el cumplimiento de la sentencia ejecutoria». Críticamente, en un caso de corrupción, García Mahamut (2005: 624 y ss.) considera que la suspensión debe ser ipso iure, siempre que concurran sus presupuestos, García San Martín (2015: 98); en contra, Llorca Ortega (2003: 199-200), quien defiende acometer una valoración previa.

99 AAP Barcelona 3. ${ }^{\text {a }}$ Ejecutoria núm. 34/2011-I, de 2-9. 
pena «durante el período de suspensión de la ejecución de la pena». Si bien queda por determinar jurisprudencialmente si se refiere a toda suspensión de pena acordada, incluida la de la solicitud del indulto, o solo a la genérica recogida en los arts. 80 y siguientes del Código Penal.

Si se opta por esta segunda solución, la solicitud del indulto se puede convertir en una nueva vía estratégica para eludir, de forma irregular, el cumplimiento de las penas impuestas, singularmente en casos de corrupción, ya que mientras se espera a que se conceda o no el indulto, podría prescribir la pena impuesta ${ }^{100}$.

Por último, suele pasar desapercibido que, en muchos Reales Decretos de concesión de indultos, se llevan a cabo una suspensión o sustitución —extrajudicial — de la pena, esto es, al margen de los requisitos establecidos en el Código Penal, y sin la debida cobertura de una ley orgánica ${ }^{101}$.

\section{DESAPODERAMIENTO JUDICIAL Y DESMORALIZACIÓN DE LOS OPERADORES JURÍDICOS}

Por último, pero no por ello menos importante, habría que destacar la desmoralización que los indultos han producido y producen en los jueces y fiscales, así como en los integrantes de los Cuerpos y Fuerzas de Seguridad del Estado, singularmente en los encargados de luchar contra la corrupción y la delincuencia económica organizada. En efecto, esta clase de procesos se caracterizan, debido a su complejidad técnica, a la multiplicidad de imputados o a las estrategias procesales de las avezadas defensas, por una elevada inversión de costosos esfuerzos materiales y personales.

Un ejemplo de esta afirmación lo constituye el Manifiesto de 29 de noviembre de 2012 que bajo la rúbrica «Contra el indulto como fraude, en defensa de la independencia judicial y de la dignidad» suscribieron unos

${ }^{100}$ Dando lugar el indulto a un tratamiento privilegiado de la prescripción de la pena en el caso de la suspensión a la que él da lugar, lo que contrasta con lo establecido en el art. 134.2 del CP, el cual expresamente declara que «El plazo de prescripción de la pena quedará en suspenso: a) Durante el período de suspensión de la ejecución de la pena».

101 Lo que con relación a los delitos de corrupción ahora es más grave, debido al cambio de la doctrina jurisprudencial, ya que — como advierte Muñoz Company (2015: 1 y ss.) - se está abandonando por parte de los tribunales la tendencia a la aplicación automática de la suspensión una vez constatada la concurrencia de los requisitos tasados legalmente para su concesión, y atendiendo preferentemente a: la concreta posición pública de los condenados, a su posible reconocimiento de los hechos, y a la alarma social que producen estos comportamientos. 
doscientos jueces ${ }^{102}$. En el citado manifiesto se afirmaba que el indulto concedido suponía un menosprecio a los miles de agentes de policía que cumplen a diario con sus funciones democráticas [...] - y- una afrenta al Poder Judicial» ${ }^{103}$.

\section{CONCLUSIONES}

1. La supresión del derecho de gracia debería estar anotada en la agenda de una futura reforma constitucional, ya que los sistemas penales democráticos pueden existir sin indulto. A este respecto habría que recordar que la Ley de 9 de agosto de 1873 derogó la vigente Ley de 1870 y suprimió los indultos, salvo para los supuestos de pena de muerte. Años antes y con otra orientación política distinta, la Reforma del Código penal de 1850, pese a la previsión constitucional, no recogía el indulto como causa de extinción de la responsabilidad penal.

Las últimas propuestas esbozadas sobre la modificación del indulto por grupos parlamentarios como Izquierda Unida ${ }^{104}$, Unión Progreso y Democracia ${ }^{105} \mathrm{o}$

102 Condena por torturas a cuatro agentes de los Mossos d'Equadra, en el que el Gobierno, en contra de los informes del tribunal sentenciador y de la Fiscalía, indulta por dos veces a los citados agentes: primero sustituyendo la inhabilitación por suspensión y reduciendo la pena privativa de libertad impuesta a dos años, para que no ingresaran en prisión. Tras ordenar la Audiencia su ingreso en prisión, por la gravedad de los hechos, se les concede un segundo indulto, y se les conmuta la pena de prisión por otra de multa. Vid. Perandones Alarcón (2013: 14 y ss.). La STEDH de 2/11/2004 apdo. 55 (Abdülsamet Yaman vs. Turquía) y la de 19/07/2012 apdo. 56 (Aleksakhin vs. Ucrania) hacen constar expresamente que en materia de torturas la concesión de una amnistía o indulto no debe ser permitida. En el mismo sentido, vid. las conclusiones y recomendaciones del Comité de las Naciones Unidas contra la Tortura (Turquía, 27 de mayo de 2003, CAT/C/CR/30/5).

103 Como afirmaba ya Dubois (1924: 309), el indulto «quita autoridad a las resoluciones de los Tribunales, suspendiéndolas, y ataca la esencia misma de la ley, limitando habitualmente el ámbito de su imperio [...]»; por su parte, Sainz De Robles (1991: 98) recalca que «No basta con que la Constitución exija el cumplimiento de las sentencias judiciales, es preciso que el órgano que las ha dictado sienta y palpe el resultado de su función».

104 Vid. Proposición de Ley del Grupo Izquierda Plural, BOCG núm. 144-1, de 22-112013.

105 Vid. BOCG núm. 196, de 18-12-2013, Proposición no de Ley 161/001096. 
el Partido Socialista Obrero Español (PSOE) ${ }^{106}$ podrían ser calificadas de tímidas y testimoniales. Tímidas porque ninguna fuerza política ha defendido su supresión total, limitándose las mismas a reformas procedimentales y/o a excluir del ámbito de aplicación del indulto ciertos delitos como los de corrupción, ya que se estima que en estos delitos nunca concurre la utilidad pública, ni el carácter excepcional, sobre todo cuando son cometidos por autoridades o funcionarios públicos. Testimoniales porque todos los grupos políticos que las han realizado están en la oposición, con lo que no existe, en este tema como en tantos otros, garantía de que, de alcanzar el poder, mantengan la concepción sustentada cuando estaban en la oposición.

En cuanto a la doctrina, la situación es paralela: solo un grupo minoritario propone su erradicación, pronunciándose la mayoría a favor de su mantenimiento, reformando la ley que lo regula, dando mayor protagonismo al poder judicial y garantizando la publicidad y transparencia del procedimiento ${ }^{107}$; o se postula como solución su posterior control jurisdiccional o por el Parlamento, u otorgar a este su concesión, soluciones todas ellas insatisfactorias, ya que no solo no evitan los problemas que genera el indulto, sino que los enquistan o crean otros nuevos.

2. No se puede asociar la pervivencia del indulto a una necesaria y constante perfectibilidad de las leyes o a la falibilidad humana no solo porque su evitación en sí misma sería una quimera, sino, sobre todo, porque tanto el sistema constitucional como el penal ya cuentan con otros medios para subsanarla. Además, como se propone en este trabajo, hay soluciones más satisfactorias y respetuosas con la separación de poderes como sería la revisión de la ejecución de la pena tardía. Por el contrario, el indulto contribuye, sobre todo cuando se conceden por delitos de corrupción, a ahondar en la creciente desconfianza hacia la ley penal, la cual es percibida como una decisión legislativa que caprichosamente puede ser dejada sin efecto, en el contexto de su constante modificación partidista.

3. En España desde el advenimiento de la democracia se han concedido más diez mil indultos, lo que denota no un uso, sino abuso de esta institución. No obstante, esta cifra guarda paralelismo con el significativo número de reformas penales sustantivas acaecidas antes y después de la promulgación del Código Penal de 1995.

En todo caso, el número de indultos concedidos en España contrasta, significativamente, con las reducidas cifras de otros estados europeos, a excep-

106 Vid. BOCG núm. 154-1, de 17/01/2014, Proposición de Ley 122/000133, de Reforma de la Ley de Indulto. Vid. también BOCG núm. 185, de 11-3-2014.

107 Por todos, Gepc (2014: 9 ss. y 23 ss.). 
ción de Italia. El Gobierno del PSOE concedió unos 3226 indultos durante sus dos legislaturas, mientras que el Partido Popular casi dobló este número, con 5916 indultos. Solo durante el año 2000, superó de largo los 1700 indultos, si bien en la última legislatura han moderado las cifras (en torno a las 800 medidas de gracia ${ }^{108}$.

Resulta, cuando menos paradójico, que en al mismo tiempo que se aprobaba la Ley Orgánica 7/2003, de 30 de junio, de Medidas de Reforma del Código Penal para el Cumplimiento Íntegro y Efectivo de las Penas, se concedieran casi seis mil indultos ${ }^{109}$.

En suma, desde un punto de vista cuantitativo se podría concluir que en España se ha pasado de los indultos generales de la época franquista, prohibidos ahora por la CE, a la generalización de los indultos particulares en la etapa democrática.

Pese a que en las grandes cifras el tráfico de drogas parecería el delito más indultado, en cifras relativas los más indultados son los delitos de corrupción. En concreto, en el período entre 1996 hasta 2010, uno de los delitos más indultados fueron las prevaricaciones de funcionarios públicos y las malversaciones de caudales públicos ${ }^{110}$.

De efectos aun incalculables en el sistema penal habría que calificar la aplicación de los indultos a las personas jurídicas ${ }^{111}$, especialmente en conde-

108 Cifras que contrastan con las de Roldán Barbero (1991: 507), quien señala que en el año 1989 se concedieron 72 indultos, de los cuales solo 15 lo fueron a instancia del juez o tribunal sentenciador.

109 Igualmente sorprende que se sigan otorgando un número significativo de indultos en el tráfico de drogas no obstante la reducción de penas o la introducción de cláusulas de moderación que llevó a cabo la LO 5/2010. En concreto, en la Exposición de Motivos de la citada Ley Orgánica se expresaba lo siguiente: «Como ha señalado autorizada doctrina penal, el mayor freno de los delitos no es la dureza de las penas, sino su infalibilidad, de modo que la certeza de un castigo, aunque este sea moderado, surtirá más efecto que el temor de otro más severo unido a la esperanza de la impunidad o de su incumplimiento [...]».

110 Vid. Doval Pais et al. (2011: 18); Belmonte; Elosúa (2013: 1); Madrid Pérez (2014: 127), hacen notar que, por ejemplo, en 2012 los más de 32 delitos de prevaricación urbanística indultados se correspondían con no más de cinco personas condenadas. Serrera Contreras (2001: 1619 y ss.) critica, por el contrario, la existencia de un derecho penal de autor en la concesión de indultos, al ser más restringido en número y efectos cuando se trata de funcionarios públicos.

111 Vid. Mayordomo Rodrigo (2013: 30 y ss.). Dos son los argumentos que abonarían tal conclusión: a) el art. 130 se refiere, de forma genérica, a «causas de extinción de la responsabilidad penal», sin realizar distingo alguno; b) una interpretación en bonam 
nas por delitos de corrupción; e igualmente funestos serían, de no derogarse la LI, los efectos que se producirían en el sistema penal si se procediera nuevamente a masivas concesiones de indultos a la difícilmente cuantificable, pero creciente cifra de previsibles condenados en los numerosos proceso penales que se siguen por delitos de corrupción.

\section{Bibliografía}

Abel Souto, M. (2013). El indulto: una propuesta para incluir en el Código Penal su regulación adaptada a principios constitucionales básicos y al Estado democrático de derecho. Revista de l'Institut Universitari d'Investigació en Criminologia i Ciències Penals de la UV (01), 2-5.

Aguado Renedo, C. (2001). Problemas constitucionales en el ejercicio de la potestad de gracia. Madrid: Civitas.

Alcácer Guirao, R. (1989). Prevención y garantías: conflicto y síntesis. Cuadernos de Filosofía del derecho (25), 5-58.

Álvarez García, F. J. (2000). Retribución y prevención general negativa como fines de la pena. Cuadernos de Politica Criminal (72), 563-614.

Aragón Reyes, M. (1998). Sistema parlamentario, sistema presidencialista y dinámica entre los poderes del Estado. Análisis comparado. En F. Pau i Vall (coord.). Parlamento y control del gobierno. V Jornadas de la Asociación Española de Letrados de Parlamento (pp. 29-45). Pamplona: Aranzadi y AELPA.

Arenal Ponte, C. (1999). El derecho de gracia ante la Justicia. Alicante: Biblioteca Virtual Miguel de Cervantes. Disponible en: http://www.cervantesvirtual.com/obra-visor/el-derecho-de-gracia-ante-la-justicia--0/html/fef9fe8e-82b1-11df-acc7-002185ce6064_2. html.

Armenta Deu, T. (1995). Pena y proceso: fines comunes y fines específicos. Anuario de Derecho Penal y Ciencias Penales (XLVIII- II), 441-464.

Asúa Batarrita, A. (2010). Lesión del derecho a un juicio sin dilaciones indebidas y proceso penal: disfunciones de la atenuación de la pena como compensación sustitutiva. Revista Vasca de Administración Pública. Herri-Arduralaritzako Euskal Aldizkaria, 87-88, $157-$ 197.

Beling, E. (1906). Die Lehre vom Verbrechen. Tübingen: JCB Mohr.

Belmonte, E. y Elosúa J. (2013). Indultos vs. condenados. El Indultómetro, Fundación Civio. Disponible en: http://www.elindultometro.es/2013/06/30/relatividad.html.

Biglino Campos, P. (1987). La iniciativa legislativa popular en el ordenamiento jurídico estatal. Revista Española de Derecho Constitucional (19), 75-130.

Bueno Ochoa, L. (2007). Elogio y refutación del indulto: estudio sobre la gracia de indulto y su regulación en el ordenamiento jurídico español. Madrid: El Boalo.

partem de las disposiciones favorables harían factible su aplicación a la extinción de la responsabilidad penal de las personas jurídicas. 
Cal Martínez, R. (2002). Las presiones del poder sobre los medios de comunicación social. Historia y Comunicación Social (7), 1-30.

Cardenal Montraveta, S. (2005). Función de la pena y suspensión de su ejecución ¿Ya no «se atenderá fundamentalmente a la peligrosidad criminal del sujeto»? InDret (4), 1-33.

Cobo del Rosal, M. y Vives Antón, T. S. (1999). derecho penal. Parte General. Valencia: Tirant lo Blanch.

Corcoy Bidasolo, M. (2012). Expansión del derecho Penal y Garantías constitucionales. Revista de Derechos Fundamentales (8), 45-76.

De Esteban, J. y López Guerra, L. M. (1983). El régimen constitucional español, I. Barcelona: Labor Universitaria.

De la Mata Barranco, N. J. (2007). El principio de proporcionalidad penal. Valencia: Tirant lo Blanch.

Del Águila Tejerina, R. (2000). Política, derecho y razón de Estado. Revista Española de Ciencia Política (3), 11-29.

Díez-Picazo Ponce de León, L. M. (1996). La criminalidad de los gobernantes. Barcelona: Crítica, D. L.

Doval País, A.; Blanco Cordero, I.; Fernandez-Pacheco Estrada, C.; Viana Ballester, C. y Sandoval Coronado, J. C. (2011). Las concesiones de indultos en España (2000-2008). Revista Española de Investigación Criminológica, 9, 1-27.

Dubois, A. (1924). Los abusos de la gracia. Revista General de Legislación y Jurisprudencia, 73, 308-312.

Espina Ramos, J. A. (2001). Indulto parcial y suspensión judicial de la pena resultante. Noticias Jurídicas Aranzadi, 105, 13-23.

Fakhouri Gómez, Y. (2010). Salud Pública (Tráfico de drogas). En Memento Experto. Reforma Penal. Madrid: Francis Lefevbre.

Fanlo Loras, A. (1991). La expedición por el rey de los decretos. En S. Martín-Retortillo (dir.). Estudios sobre la Constitución española. Homenaje al profesor Eduardo García de Enterría III (La Corona. Las Cortes Generales. Del Gobierno y de las Administración Pública). Madrid: Civitas.

Gallego Soler, I. (2011). Art. 368. En M. Corcoy Bidasolo y S. Mir Puig (dirs.). Comentarios al Código penal. Valencia: Tirant lo Blanch.

Garberí Llobregat, J. (2008). El derecho a la tutela judicial efectiva en la jurisprudencia del Tribunal Constitucional. Barcelona: Bosch.

García Arán, M. (2009). Repercusiones penales de la Ley de Amnistía de 1977. En M. J. Espuny Tomas y O. Paz Torres (coords.). 30 Años de la Ley de Amnistía (1977-2007). Madrid: Dykinson.

- y Peres-Neto, L. (2008). Discursos mediáticos y reformas penales de 2003. En M. García Arán y J. Botella Corral (dirs.). Malas noticias, medios de comunicación, política criminal y garantías penales en España (pp. 261-290). Valencia: Tirant lo Blanch.

García de Enterría Martínez-Carande, E. (1962). La lucha contra las inmunidades del poder en el derecho administrativo (poderes discrecionales, poderes de gobierno, poderes normativos). Revista de Administración Pública (38), 159-208.

García Mahamut, R. (2000). La responsabilidad penal de los miembros del Gobierno en la Constitución. Madrid: Tecnos. 
- (2004). El indulto. Un análisis jurídico-constitucional. Madrid: Marcial Pons.

- (2005). Seis reflexiones sobre el indulto y una consideración acerca de la suspensión de la ejecución de la pena ante la solicitud de indulto. En L. Aguiar de Luque (coord.). Constitución, estado de las autonomías y justicia constitucional: (Libro Homenaje al profesor Gumersindo Trujillo) (pp. 611-628). Valencia: Tirant lo Blanch.

García-Pelayo, M. (1983). La división de poderes y su control jurisdiccional. Revista de Derecho Politico, 18-19, 7-16.

García Roca, F. J. (2000). Del principio de la división de poderes (1). Revista de Estudios Políticos (108), 41-75.

García San Martín, J. (2015). Las medidas alternativas al cumplimiento de las penas privativas de libertad. Madrid: Dykinson.

Gemma G. (1973). Profili costituzionali dell'amnistia, dell'indulto e del condono fiscali. Archivio Giuridico Filippo Serafini (184), 35-80.

Giménez García, J. (2013). Tutela judicial efectiva vs derechos de las víctimas, dilaciones indebidas, prescripción e indultos. Eguzkilore (27), 31-42.

Gómez Colomer, J. L. (2001). La revisión en el proceso penal español. Doctrina y Jurisprudencia (7), 221-227.

Grupo de Estudios de Política Criminal (2014). Una alternativa a algunas previsiones penales utilitarias (Indulto, prescripción, dilaciones indebidas y conformidad procesal). Valencia: GEPC-Tirant lo Blanch.

Herrero Bernabé, I. (2012). Antecedentes históricos del indulto. Revista de Derecho de la UNED (10), 687-709.

Gimeno Sendra, V. (2013). Corrupción y propuestas de reforma. Diario La Ley (18), 1-6.

- y Díaz Martínez, M. (2011). Manual de derecho procesal penal. Madrid: Colex.

Lafuente Balle, J. M. (1997). Art. 62 (apartados f-j). En Ó. Alzaga Villamil (dir.). Comentarios a la Constitución española de 1978 (t. v.). Madrid: EDERSA.

Linde Paniagua, E. (1976). Amnistía e indulto en España. Madrid: Tucar.

- (1998). La clemencia (amnistía e indulto) a la luz de la jurisprudencia de los Tribunales Supremo y Constitucional y del Código Penal de 1995. Boletín del Ministerio de Justicia (1823), 1413-1428.

- (2000). El indulto como acto de administración de Justicia y su judicialización: Problemas, límites y consecuencias. Teoría y Realidad Constitucional (5), 161-176.

Lascuraín Sánchez, J. A. (1998). La proporcionalidad de la norma penal. Cuadernos de Derecho Público (5), 159-89.

López Aguilar, J. F. (1996). Una reflexión a propósito del control parlamentario del ejercicio del derecho de gracia. Revista de las Cortes Generales (37), 329-342.

- (2004). Prólogo a Rosario García Mahamut. El indulto. Un análisis jurídico-constitucional. Madrid: Marcial Pons.

Lozano Cutanda, B. (1991). El indulto y la amnistía ante la Constitución. En S. Martín-Retortillo (coord.). Estudios sobre la Constitución española: Homenaje al profesor Eduardo García de Enterría, 2 (pp. 1027-1053). Madrid: Civitas.

Lucas Garín, A. (2009). Nuevas dimensiones del principio de división de poderes en un mundo globalizado. Estudios Constitucionales (2), 241-253. Disponible en: http://dx.doi. org/10.4067/s0718-52002009000200009. 
Lucas Verdú, P. (1974). Curso de derecho Politico. V. II. Madrid: Tecnos.

Luzón Peña, D. M. (1979). Medición de la pena y sustitutivos penales. Madrid: Instituto de Criminología de la Universidad de Madrid.

- (1989). Alcance y Función del derecho penal. Anuario de derecho penal y Ciencias Penales (XLII), 5-54.

- (1991). Estudios Penales. Madrid: PPU.

Llorca Ortega, J. (2003). La ley de indulto: (comentarios, jurisprudencia, formularios y notas para su reforma). Valencia: Tirant lo Blanch.

Malem Seña, J. F. y Selee, H. O. (2013). Patologías de la división de poderes. DOXA, Cuadernos de Filosofía del Derecho (36), 275-296.

Magro Servet, V. (2007). La petición de suspensión de ejecución de la pena por tramitación de indulto. La Ley Penal (39), 101-107.

- (2013). Particularidades de la medida de gracia del indulto frente a las decisiones el poder judicial. La Ley Penal (103), 1-8.

Manzanares Samaniego, J. L. (2010). Código penal. Granada: Comares.

Mapelli López, E. (1997). La liberación de un penado en la Semana Santa de Málaga. Isla de Arriarán: revista cultural y científica (9), 159-170.

Mayordomo Rodrigo, V. (2013). El indulto de las personas jurídicas. Fundamento en «razones de equidad, justicia o utilidad pública. En J. L. De la Cuesta Arzamendi (dir.) y N. de la Mata Barranco (coord.). Responsabilidad penal de las personas. Jurídicas. Pamplona: Aranzadi.

Mir Puig, S. (1986). Función fundamentadora y función limitadora de la prevención general positiva. Anuario de Derecho Penal y Ciencias Penales (39), 49-58.

- (2015) Derecho penal. Parte General. Barcelona: Reppetor.

Miró Llinares, F. y Bautista Ortuño, R. (2013). ¿Por qué cumplimos las normas penales? Sobre la disuasión en materia de seguridad vial. InDret (4), 1-53.

Molina Fernández, F. (2011). Memento Práctico Francis Lefebvre. Penal 2011. Madrid: Ediciones Francis Lefebvre.

Morales Prats, F. (2011). Art. 130. En G. Quintero Olivares (dir.). Comentarios al Código Penal español. Pamplona: Aranzadi.

Mortati, C. (1973). Le forme di governo. Padua: Cedam.

Muñoz Company, M. J. (2015). Delitos de corrupción política: ejecución de las penas, posibilidad de suspensión y sustitución de estas: modificación por la Ley Orgánica 1/2015. Análisis jurisprudencial. Diario La Ley (8589), 1-3.

Muñoz Conde, F. y García Arán, M. (2010). Derecho penal. Parte General. Valencia: Tirant lo Blanch.

Navarro Villanueva, C. (2009). Notas acerca del indulto. En M. J. Espuny i Tomás, O. Paz Torres y P. Ysàs Solares (coords.). 30 años de la Ley de Amnistía: (1977-2007) (pp. 227252). Madrid: Dykinsons-UAB.

Nieva Fenoll, J. (2013). Proceso penal y delitos de corrupción (algunas bases para la reforma estructural en el proceso penal. InDret, 2, 1-22.

Obregón García, A. (1996). La responsabilidad criminal de los miembros del Gobierno: análisis del art. 102 de la Constitución española. Madrid: Civitas. 
Ortego Pérez, F. (2013). El indulto: controversias de su ejercicio y necesidad de reforma. Iuris: Actualidad y Práctica del Derecho, 187, 12-15.

Ortiz de Urbina, I. (2012). Política criminal contra la corrupción: Una reflexión desde la teoría de la pena (o viceversa). En S. Mir Puig y M. Corcoy Bidasolo (dirs.). Garantías constitucionales y derecho penal europeo. Madrid: Marcial Pons.

Orts Berenguer, E. y González Cussac, J. L. (2004). Compendio de derecho penal (parte general $y$ parte especial). Valencia: Tirant lo Blanch.

Pacheco Gutiérrez Calderón, F. (1836). El derecho de gracia o de la remisión y conmutación de las penas. Boletín de Jurisprudencia y Legislación, t. 1. Madrid: Imprenta de D. Tomás Jordán.

- (1843): Estudios de derecho Penal, t. II. Madrid: Juan Manuel Tello.

Peña Neira, S. (2012). La división de poderes y su control por medio de la prensa. Ars Boni et Aequi (1), 205-214.

Perandones Alarcón, M. (2013). El indulto y la interdicción de la arbitrariedad de los poderes públicos. La Ley Penal, 103, 10-21.

Pérez Francesch, J. L. (2009). Amnistía, indulto e intencionalidad política. En M. J. Espuny i Tomás, O. Paz Torres y P. Ysàs Solares (coords.). 30 años de la Ley de Amnistía: (19772007) (pp. 56-679). Madrid: Dykinson-UAB.

Pérez Francesch, J. L. y Domínguez García, F. (2002). El indulto como acto del Gobierno: una perspectiva constitucional (especial análisis del «caso Liaño»). Revista de Derecho Político (53), 25-74. Disponible en: http://dx.doi.org/10.5944/rdp.53.2002.8839.

Punset Blanco, R. (2009). Presentación. Fundamentos. Cuadernos Monográficos de Teoría del Estado, Derecho Público e Historia Constitucional, División de Poderes (5), 11-18.

Queralt Jiménez, J. J. (1992). Código Penal y ley orgánica. Anuario de Derecho Penal y Ciencias Penales, 45 (1), 49-83.

- (2014). ¿No habrá más indultos para los corruptos? Disponible en: www.eldiario.es/agendapublica/nueva-politica/indultos-corruptos_0_281722404.

Requejo Pagés, J. L. (2001). Amnistía e indulto en el constitucionalismo histórico español. Historia constitucional: Revista Electrónica de Historia Constitucional (2), 81-106.

Rey Martínez, F. (2012). ¿Es constitucional la presencia del crucifijo en las escuelas públicas? Revista Jurídica de Castilla y León, 27, 1-32.

Rodríguez Mourullo, G. (1996). Criterios para la exigencia de responsabilidad criminal al presidente y demás miembros del Gobierno: art. 102. En Ó. Alzaga Villaamil (dir.). Comentarios a la Constitución española de 1978 (t. VIII, pp. 369-379). Madrid: EDERSA.

Roldán Barbero, H. (1991). Indulto e individualización de la pena. En P. Lucas Murillo de la Cueva y J. I. Font Galán (coords.). Estudios jurídicos: en conmemoración del X aniversario de la Facultad de Derecho (v. 2, pp. 497-512). Córdoba: Universidad de Córdoba.

Rubio Llorente, F. (2004). Separación de poderes y democracia en la Constitución. En G. Peces-Barba Martínez y M. A. Ramiro Avilés (coords.). La Constitución a examen. Un estudio académico 25 años después (pp. 223-256). Madrid: Marcial Pons.

- (2009). Quizá España no vaya tan bien. El País. Disponible en: http://elpais.com/diario/1999/10/25/opinion/940802404_850215.html.

Sainz de Robles Rodríguez, F. (1991). El indulto como atentado a la independencia del juez. Cuenta y Razón (55), 97-98. 
Salvini, G. (1981). La grazia: attualitá dellistituto e problemi di legitimita costituzionale. $R i-$ vista Italiana di Diritto e Procedura Penale (3), 1007-1013.

Sánchez-Vera Gómez-Trelles, J. (2008). Una lectura crítica de la Ley de Indulto, InDret (2), $1-32$.

Sequeros Sazatornil, F. (2005). El control sobre la razonabilidad del indulto desde el plano constitucional. La Ley: Revista Jurídica Española de Doctrina, Jurisprudencia y Bibliografia (5), 962-969.

Serrera Contreras, P. L. (2001). ¿El indulto para todos? La Ley: Revista Jurídica Española de Doctrina, Jurisprudencia y Bibliografia (7), 1619-1625.

Silva Sánchez, J. M. (2007). La teoría de la determinación de la pena como sistema (dogmático): un primer esbozo. InDret (2), 1-15.

Solozabal Echavarría, J. J. (1981). Sobre el principio de separación de poderes. Revista de Estudios Políticos (24), 215-234.

Varona Gómez, D. (2011). Medios de comunicación y punitivismo. InDret (2), 1-35.

Wittreck, F. (2009). División, limitación y organización de poderes la concepción de las funciones estatales en la Ley Fundamental de Bonn (trad. L. Álvarez Álvarez). Fundamentos: Cuadernos Monográficos de Teoría del Estado, Derecho Público e Historia Constitucional (5), 1-50.

Zagrebelsky, G. (1974). Amnistía, indulto e grazia: profili costituzionali. Milán: Giuffrè.

Zugaldía Espinar, J. M. (2010). Fundamentos de derecho penal. Parte General. Valencia: Tirant lo Blanch. 
